\title{
Characterization of Ameboid Microglia Isolated from Developing Mammalian Brain
}

\author{
Dana Giulian and Timothy J. Baker \\ Department of Neurology and Program of Neuroscience, Baylor College of Medicine, Houston, Texas 77030
}

\begin{abstract}
Ameboid microglia are isolated from the cerebral tissue of neonatal rat by selective cell adhesion to plastic. Histochemical markers show that the microglial preparations are homogeneous $(95 \pm 3 \%)$ and represent a $10 \%$ yield from starting cultures. Isolated ameboid microglia contain nonspecific esterase activity, the macrophage surface antigens $\mathrm{MAC}-1$ and $\mathrm{MAC}-3$, and acetylated low-density lipoprotein receptors. Ameboid cells have functional properties similar to those of macrophages, including the ability to engulf $5 \mu \mathrm{m}$ latex beads, to secrete Interleukin-1 (IL-1) and to release superoxide anion. Unlike monocytes and adherent spleen cells, ameboid microglia do not show peroxidase activity by histochemical stain. Unlike resident peritoneal macrophages, ameboid microglia proliferate in vitra. Scanning electron microscopy shows that ameboid cells have short, spinous processes that can be distinguished from the ruffled surfaces of body macrophages. Our observations suggest that ameboid microglia are a distinct class of mononuclear phagocytic cells.
\end{abstract}

Retinoic acid and dimethyl sulfoxide, agents known to accelerate differentiation in vitro, stimulate ameboid cells to develop thin processes several hundred microns in length. These "process-bearing" microglia eventually lose the capacity to engulf latex beads and to proliferate. They also show reductions in nonspecific esterase activity and in the binding of acetylated low-density lipoprotein. We suggest that in vitro ameboid microglia differentiate in:o nonphagocytic cells similar to ramified microglia found in normal adult brain. The isolation techniques described here provide the opportunity to study the composition and function of different microglial subpopulations during the development of the CNS.

Rio-Hortega (1932) was the first to recognize microglia as a distinct population of cells within the CNS. He found that microglia respond to brain injury by migrating to sites of tissue damage, by undergoing marked changes in morphology, by proliferating, and by engulfing tissue debris (Oehmichen, 1983; Privat and Fulcrand, 1977; Rio-Hortega, 1932). Two principal forms of microglia have been described. Ameboid cells, also

\footnotetext{
Received Sept. 12, 1985; revised Jan. 14, 1986; accepted Feb. 11, 1986.

We thank Drs. Wayne Koff and Lawrence B. Lachman of the Department of Cell Biology, M. D. Anderson Tumor Institute, and Dr. David Via of the Department of Medicine, Baylor College of Medicine, for their discussions and suggestions. We also thank Dr. Lachman for performing the Interleukin-1 assay and acknowledge Dr. Via's proposal for the use of 1,1'-dioctadecyl-3,3,3',3'-tetramethyl-indocarbocyanate as a microglial marker. We are grateful to Joan Bales, Ivey Burton, Bhavna Shah, Anh Thuy Nguyen, Ai-Nhi Tran, and Douglas G. Young for their technical assistance, and to Dr. Corazon Bucana and Mr. John Willard for the scanning electron photomicrographs. This work was supported by NIH Grants ROI-EY04915 and R01-N\$2063801; a Teacher Investigator Award (NS00806) from the National Institute of Neurological and Communicative Disorders and Stroke; by a Basil O'Conner Starter Research Grant from the March of Dimes; and by funds from the Kroc Foundation.

Correspondence should be addressed to Dr. Giulian, Department of Neurology, One Baylor Plaza, Baylor College of Medicine, Houston, TX 77030.

Copyright (c) 1986 Society for Neuroscience $0270-6474 / 86 / 082163-16 \$ 02.00 / 0$
}

referred to as gitter cells or reactive microglia, are morphologically similar to monocytes and macrophages (Innocenti et al., 1983a; Ling, 1981; Oehmichen, 1983; Stensaas and Reichart, 1971; Torvik, 1975; Valentino and Jones, 1981). They appear in the CNS during late stages of embryogenesis at sites of axonal growth and glial proliferation. The ameboid cells disappear by the late postnatal period but are again detected at sites of CNS damage in adults (Boya et al., 1979; Brierley and Brown, 1982; Murabe and Sano, 1982; Rio-Hortega, 1932; Tseng et al., 1983). Numerous anatomical studies support Rio-Hortega's original proposal that ameboid microglia serve as the principal scavenger cells of the brain (Ling, 1981; Oehmichen, 1983) not only during neuropathic conditions, but also during CNS development. Innocenti and co-workers (1983a, b) and Matsumoto and Ikuta (1985) have suggested, for example, that ameboid microglia engulf misplaced axons to aid organization of the perinatal brain. Although the origin of ameboid microglia remains uncertain, these cells are similar to and perhaps share a common origin with other classes of phagocytic mononuclear cells (Ling, 1981; Oehmichen, 1983; Rio-Hortega, 1932).

The "ramified" cell represents a second form of microglia (Murabe and Sano, 1982; Oehmichen, 1983; Rio-Hortega, 1932), which appears during the late postnatal period and persists throughout adult life. Ramified microglia have processes of various lengths, lack hydrolytic enzymes, and are not capable of engulfing particles (Oehmichen, 1983). Although the nature of the relationship between ameboid and ramified microglia is controversial, studies using histochemistry and electron microscopy have suggested that the ameboid cells differentiate into ramified cells during postnatal development (Ling, 1981; Murabe and Sano, 1982). Ramified cells are generally viewed as "quiescent" microglia that lack monocytic properties. The function of ramified microglia is unknown.

Aside from morphologic studies, the investigation of microglial biology has been quite limited (Ling, 1981). In order to characterize the interactions betwecn microglia and other cells of the brain, we developed methods to obtain highly enriched preparations of ameboid microglia from mammalian CNS. We found that, although ameboid cells had surface antigens and secretion products in common with other mononuclear phagocytic cells, ameboid microglia could be distinguished from monocytes and body macrophages by histochemical staining, by a proliferative capacity, and by cell surface morphology. Moreover, isolated ameboid microglia differentiated into "process-bearing" cells that resembled ramified microglia found in the adult CNS.

\section{Materials and Methods}

\section{Cell cultures}

Resident macrophages were obtained from newborn and adult albino rats (Holtzman, Madison, WI) by lavage of the peritoneal cavity (Daems, 1980), and monocytes by a Ficoll hypaque gradient (Mosier, 1981). 

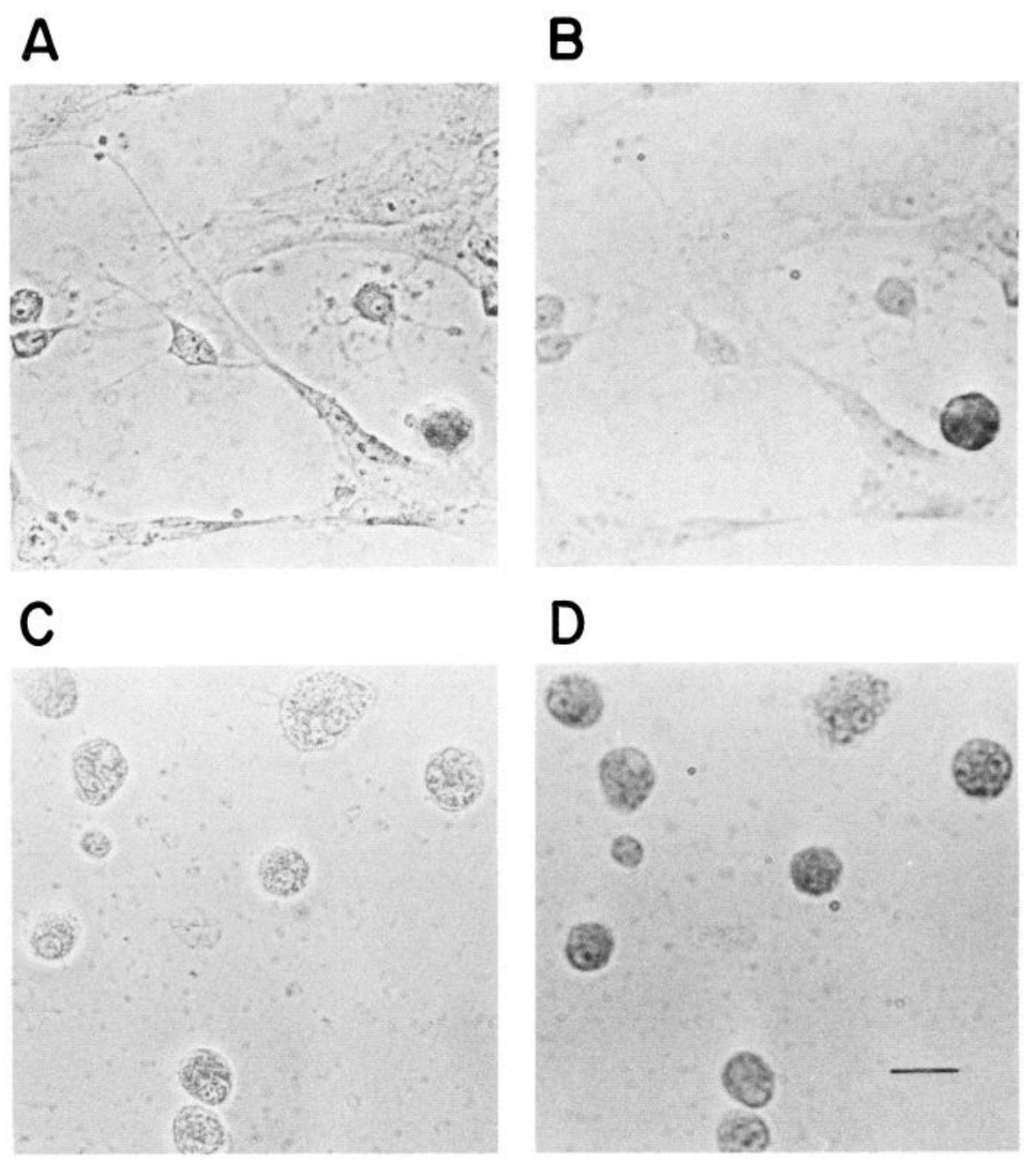

Figure 1. Nonspecific esterase activity within glia obtained from newborn rat cerebral tissue. Between 5 and $10 \%$ of cells in mixed cultures showed a dark reaction product, indicating esterase activity $(B)$. Enriched microglia preparations isolated by adhesion methods (see Table 1) showed a nearly homogeneous population of nonspecific esterase $(+)(D)$. Phase photomicrographs ( $A$ and $C$ ) show the total cell population $24 \mathrm{hr}$ after plating, while bright-field photomicrographs ( $B$ and $D$ ) show nonspecific esterase $(+)$ cells. Bar, $25 \mu \mathrm{m}$.

Spleen cells adherent to plastic were recovered from newborn and adult rats (Beller, 1981). Microglia were isolated from cultures of newborn rat brain, as described in Results, with tissue dissociated by trituration in the presence of $0.2 \%$ trypsin (Type $111-\mathrm{S}$; Sigma). L-leucine methyl ester (Sigma) served as a lysosomotrophic agent to destroy mononuclear phagocytic cells (Thiele et al., 1983).

Enriched preparations of astroglia were obtained by the method of McCarthy and de Vellis (1980). Astroglia were grown on poly-L-lysinecoated $22 \mathrm{~mm}^{2}$ glass coverslips in $35 \mathrm{~mm}$ culture dishes containing 1.5 ml chemically defined medium (Bottenstein and Sato, 1979; Giulian et al., 1985).

\section{Cell identification}

Histochemistry for nonspecific esterase and peroxidase was carried out by standard methods (Kaplow, 1981; Koski et al., 1976). As described previously (Giulian et al., 1985), indirect immunofluorescence techniques were used to identify astroglia containing glial fibrillary acidic protein (GFAP) and oligoendroglia containing galactocerebroside (GC). The surface antigens MAC-1 and MAC-3 (Springer and Ho, 1982) were identified by indirect immunofluorescence with mouse monoclonal antibody (1:25; Hybritech, San Diego, CA) and anti-mouse IgG conjugated to fluorescine (1:50; Accurate Chemicals, Westbury, NY). The acetylated low-density lipoprotein, labeled with the fluorescent probe $1,1^{\prime}$ dioctadecyl-3,3,3', $3^{\prime}$-tetramethyl-indocarbocyanate (DIL-ac-LDL), was used to identify mononuclear phagocytic cells. Cultures were incubated for $6-12 \mathrm{hr}$ at $37^{\circ} \mathrm{C}$ with DIL-ac-LDL in concentrations ranging between 5 and $15 \mu \mathrm{g}$ per ml of culture medium. Cells were then fixed with $3 \%$ formaldehyde in PBS (pH 7.2) at room temperature for $1 \mathrm{hr}$, washed with PBS, and viewed with a fluorescence microscope (Nikon).
Cells adhering to glass coverslips were fixed for $2 \mathrm{hr}$ with $2.5 \%$ glutaraldehyde in PBS at room temperature and processed for scanning electron microscopy (Sone et al., 1981).

\section{Cell activation and biological assays}

The assay for Interleukin-1 (IL-1) was performed by Dr. Lawrence B. Lachman (Department of Cell Biology, M. D. Anderson Tumor Institute, Houston, TX) using mouse thymocytes, as described elsewhere (Giulian and Lachman, 1985a). Suspensions of fixed Staphylococcus aureus, $20 \mu \mathrm{l}$ suspended bacteria per $\mathrm{ml}$ Pansorbin (Calbiochem), or lipopolysaccharide (LPS), $5 \mu \mathrm{g} / \mathrm{ml}$ (Sigma), served as inducers of IL-1 release (Dinarello, 1984). Dimethyl sulfoxide (DMSO), 1\% vol/vol (Sig$\mathrm{ma}$ ) and solutions of retinoic acid, 0.1-1.0 $\mu \mathrm{M}$ (Sigma), were used to induce differentiation. Recombinant Interleukin-3 (IL-3) was a gift from Dr. Lachman. Partially purified IL-3 from the WEHI-3 cell line (Lee et al., 1982) was a gift from Dr. John Lee of Smith, Kline and French Laboratories (Philadelphia, PA). The proliferation of ameboid microglia was monitored by scoring the cell number found in randomly selected fields $\left(0.314 \mathrm{~mm}^{2}\right)$. The production of superoxide anion induced by phorbol myristate acetate (PMA; Sigma) was monitored by quantitating the reduction of cytochrome C at $550 \mathrm{~nm}$ (Johnston, 1981) using superoxide dismutase to determine reaction specificity.

\section{Results}

\section{Isolation of ameboid microglia}

Histochemical study by Ling and co-workers has shown that newborn rat brain contained large numbers of nonspecific es- 
Table 1. Isolation of ameboid microglia

\begin{tabular}{lc} 
Step & $\begin{array}{c}\text { Time re- } \\
\text { quirement }\end{array}$ \\
\hline 1. Dissociation of cerebral tissue from newborn rat & $2 \mathrm{hr}$ \\
2. Mixed glial culture grown in plastic flasks & $7 \mathrm{~d}$ \\
3. Vigorous agitation, rotatory shaker, $180 \mathrm{rpm}, 37^{\circ} \mathrm{C}$ & $15 \mathrm{hr}$ \\
4. First adhesion step in plastic flasks, $37^{\circ} \mathrm{C}$ & $1-3 \mathrm{hr}$ \\
5. Gentle agitation by hand, $20^{\circ} \mathrm{C}$ & $2-5 \mathrm{~min}$ \\
6. Second adhesion step in plastic flask, $37^{\circ} \mathrm{C}$ & $1-3 \mathrm{hr}$ \\
7. Gentle agitation by hand, $20^{\circ} \mathrm{C}$ & $2-5 \mathrm{~min}$
\end{tabular}

Isolation of microglia by sequential adhesion. Mixed glial populations werc obtained from dissociated cerebral tissue of newborn rat (Giulian et al., 1985) and grown in chemically defined medium (Bottenstein and Sato, 1979) containing $10 \%$ fetal calf serum for $7 \mathrm{~d}$ on plastic tissue culture flasks. Microglia were freed from the starting culture flask by $15 \mathrm{hr}$ of vigorous agitation on a rotatory shaker $(180 \mathrm{rpm})$ at $37^{\circ} \mathrm{C}$ and selected out by a series of adhesion steps to plastic culture flasks. Gentle agitation of flasks was performed by hand for $5 \mathrm{~min}$ at room temperature and monitored by phase microscopy. Twelve brains provided material for 1075 $\mathrm{cm}^{2}$ plastic flasks.

terase(+) ameboid microglia. (Leong et al., 1983; Ling, 1976, 1981). We observed that about $5 \%$ of cells obtained from dissociated newborn rat brain were phagocytic, ameboid-shaped, and nonspecific esterase(+) (Fig. 1). Such cells were similar to those ameboid, phagocytic cells described by Raff et al. (1979) in cultures of dissociated rat brain. Our desire to isolate ameboid microglia from cell culture formed the starting point for this study.

Isolated cerebral cortices from newborn albino rats were stripped of the meninges, minced in a chemically defined culture medium (Bottenstein and Sato, 1979) and dissociated by trituration in $0.25 \%$ trypsin in PBS. Cells were plated in $75 \mathrm{~cm}^{2}$ plastic culture flasks containing $10 \mathrm{ml}$ defined medium with $10 \%$ fetal bovine serum at a density of 850,000 cells $/ \mathrm{ml}$. After $7 \mathrm{~d}$, confluent cultures were vigorously agitated on a rotary shaker for $15 \mathrm{hr}\left(37^{\circ} \mathrm{C}, 180 \mathrm{rpm} ; \mathrm{McC}\right.$ arthy and de Vellis, 1980). GFAP $(+)$ astroglia remained adherent to the flasks. The resulting cell suspension, rich in ameboid microglia and oligodendroglia, was placed in plastic flasks $(100,000$ cells $/ \mathrm{ml})$ and allowed to adhere at $37^{\circ} \mathrm{C}$. We noted that within $3 \mathrm{hr}$ most of the cells that adhered to the plastic were nonspecific esterase $(+)$ (Figs. 1 and 2). From this observation, we developed an isolation procedure for ameboid microglia (Table 1) that also permitted recovery of astroglia and oligodendroglia. After a 1-3 hr adhering interval, loosely adhering and suspended cells (most of which were oligodendroglia) were removed by gently shaking flasks at room temperature. The strongly adhering microglia were then released by

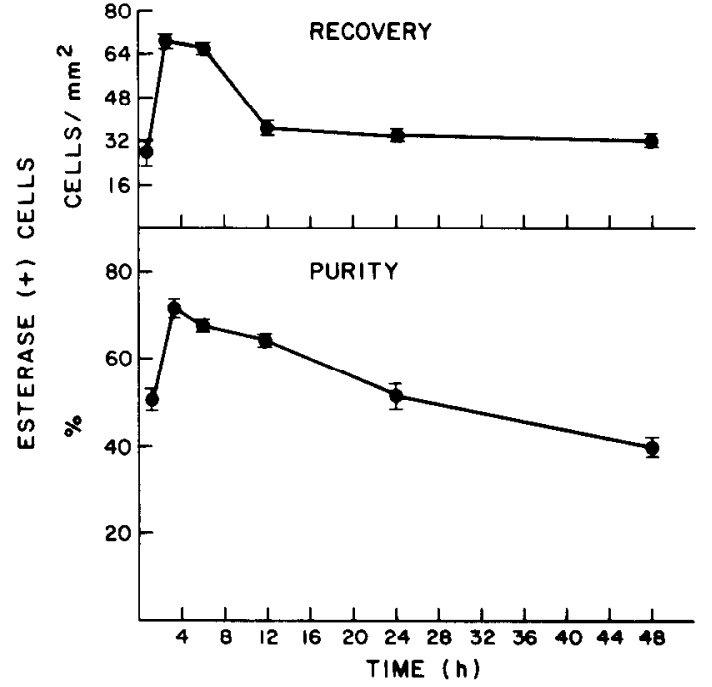

Figure 2. Adhesion of nonspecific esterase $(+)$ ameboid microglia to plastic culture flasks in the presence of defined medium containing $10 \%$ fetal bovine serum. Top, Cells released by vigorous agitation from mixed glial starting cultures were found to adhere to plastic with optimal recovery after $2-6 \mathrm{hrs}$. Bottom, After a $4 \mathrm{hr}$ incubation, $70 \%$ of all adhering cells were nonspecific esterase $(+)$ ameboid microglia.

vigorous shaking in defined medium with $0.2 \%$ trypsin. Once the majority of the microglia had been resuspended, fetal bovine serum was added ( $15 \%$ final volume), and the cell suspension added to new plastic flasks. After a second 1-3 hr interval to allow adhesion, the medium was removed, and adhering microglia were resuspended using trypsin. Final preparations showed a nearly homogeneous population of nonspecific esterase $(+)$ cells with $95 \%$ enrichment when monitored $24 \mathrm{hr}$ after plating. These cells were $\operatorname{GFAP}(-)$ and $\mathrm{GC}(-)$. There was a $10 \%$ recovery of all nonspecific esterase $(+)$ microglia that had been found in the starting cultures (Fig. 1, Table 2). GC(+) oligodendroglia and GFAP( + ) astroglia were nonspecific esterase $(-)$ and made up less than $0.5 \%$ of the microglial cultures. Our "warm-shake" method allowed isolation not only of enriched populations of ameboid microglia, but of enriched suspensions of $\mathrm{GC}(+)$ oligodendroglia and adhering $\mathrm{GFAP}(+)$ astroglia (McCarthy and de Vellis, 1980).

In addition, we found that microglia could be isolated rapidly by agitating the starting culture flasks (rotating shaker, $180 \mathrm{rpm}$ ) for $30 \mathrm{~min}$ at $4^{\circ} \mathrm{C}$. The resulting cell suspensions contained 50 $60 \%$ nonspecific esterase $(+)$ microglia with an estimated 60

Table 2. Recovery of ameboid microglia from cultures of dissociated rat brain

\begin{tabular}{|c|c|c|c|c|c|}
\hline & \multirow{2}{*}{$\begin{array}{l}\text { Nonspecific } \\
\text { esterase } \\
(\%)^{a}\end{array}$} & \multicolumn{3}{|c|}{$\begin{array}{l}\text { Ameboid microglia in total } \\
\text { cell population }(\%)\end{array}$} & \multirow{2}{*}{$\begin{array}{l}\text { Ameboid } \\
\text { cell recovery } \\
\text { from mixed } \\
\text { cultures (\%) }\end{array}$} \\
\hline & & $\begin{array}{l}\text { DIL-ac- } \\
\text { LDL }^{b}\end{array}$ & MAC-1 ${ }^{c}$ & ${\mathrm{MAC}-3^{c}}^{c}$ & \\
\hline Mixed culture & $5 \pm 3$ & $4 \pm 1$ & $6 \pm 1$ & $4 \pm 2$ & 100 \\
\hline First adhesion step & $71 \pm 4$ & $73 \pm 7$ & $77 \pm 5$ & $66 \pm 6$ & $75 \pm 10$ \\
\hline Second adhesion step & $95 \pm 3$ & $92 \pm 5$ & $93 \pm 4$ & $92 \pm 5$ & $10 \pm 2$ \\
\hline
\end{tabular}

The recovery of ameboid microglia from cultures of brain cells, isolated as described in Table 1. Four different markers were used to identify ameboid microglia. The data are mean values \pm SE calculated from 10 randomly selected fields $\left(0.314 \mathrm{~mm}^{2}\right)$ for at least 4 cultures. Percentage recovery is based upon an estimate of total number of ameboid cells found in starting cultures grown in plastic flasks.

a Histochemical marker common to many monocytic phagocytes (Kaplow, 1981).

${ }^{b}$ Fluorescent probe used to identify acetylated low-density lipoprotein receptors (Pitas et al., 1981).

c Macrophage surface antigens (Springer and Ho, 1982). 

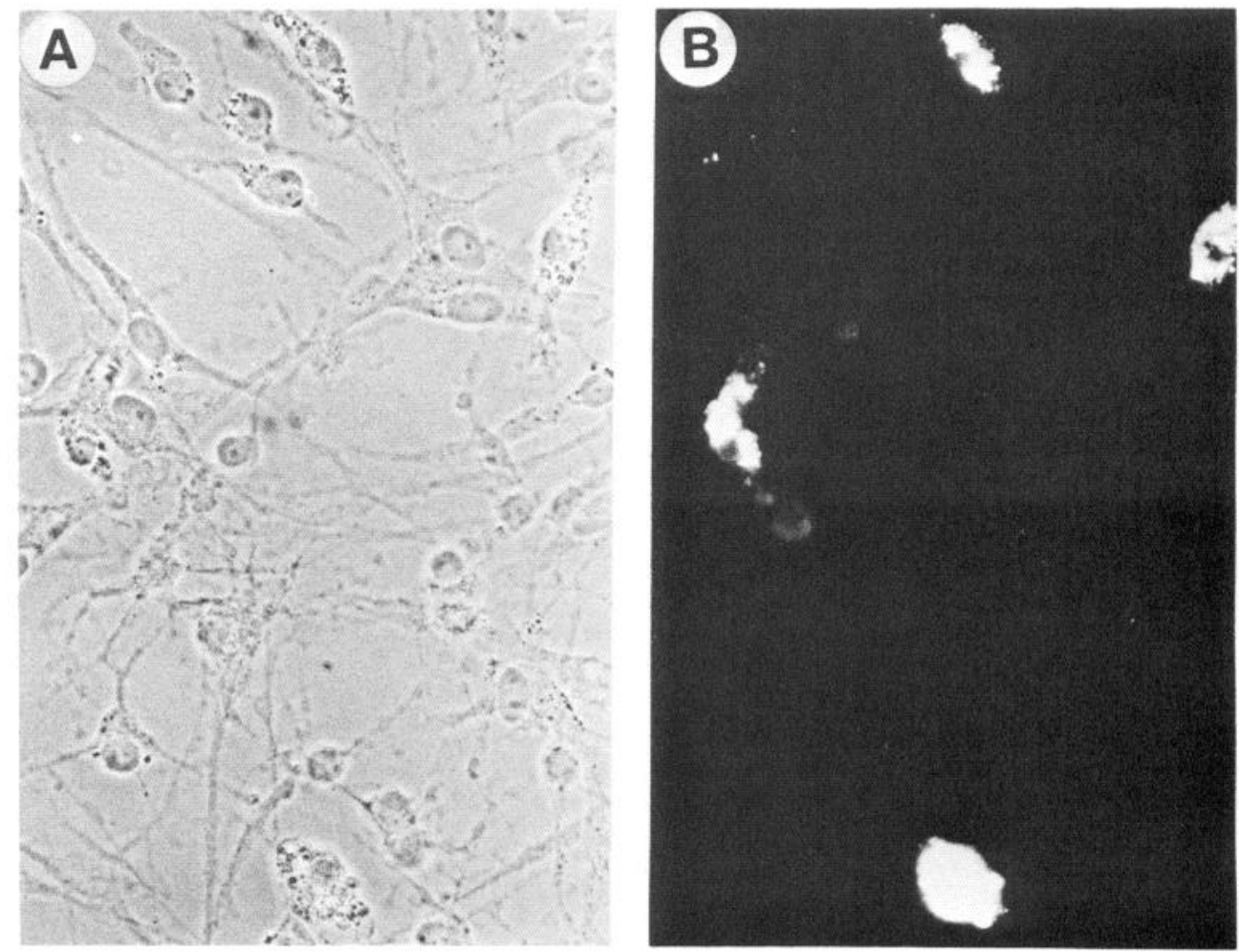

Figure 3. Presence of acetylated lowdensity lipoprotein receptor in ameboid microglia. $A$ and $B$, About $5 \%$ of cells of starting cultures of mixed glial populations grown from newborn rat brain contained acetylated LDL receptors, as shown by the fluorescent probe DIL-ac-LDL. $C$ and $D$, Nearly all cells found in enriched cultures of ameboid microglia bound DIL-ac-LDL. As shown in the phase photomicrographs $(A$ and $C$ ), microglia were densely packed with vesicles after a $12 \mathrm{hr}$ incubation with the probe. Cultures were monitored for $72 \mathrm{hr}$ prior to incubation with DIL-ac-LDL. Bar, $25 \mu \mathrm{m}$.
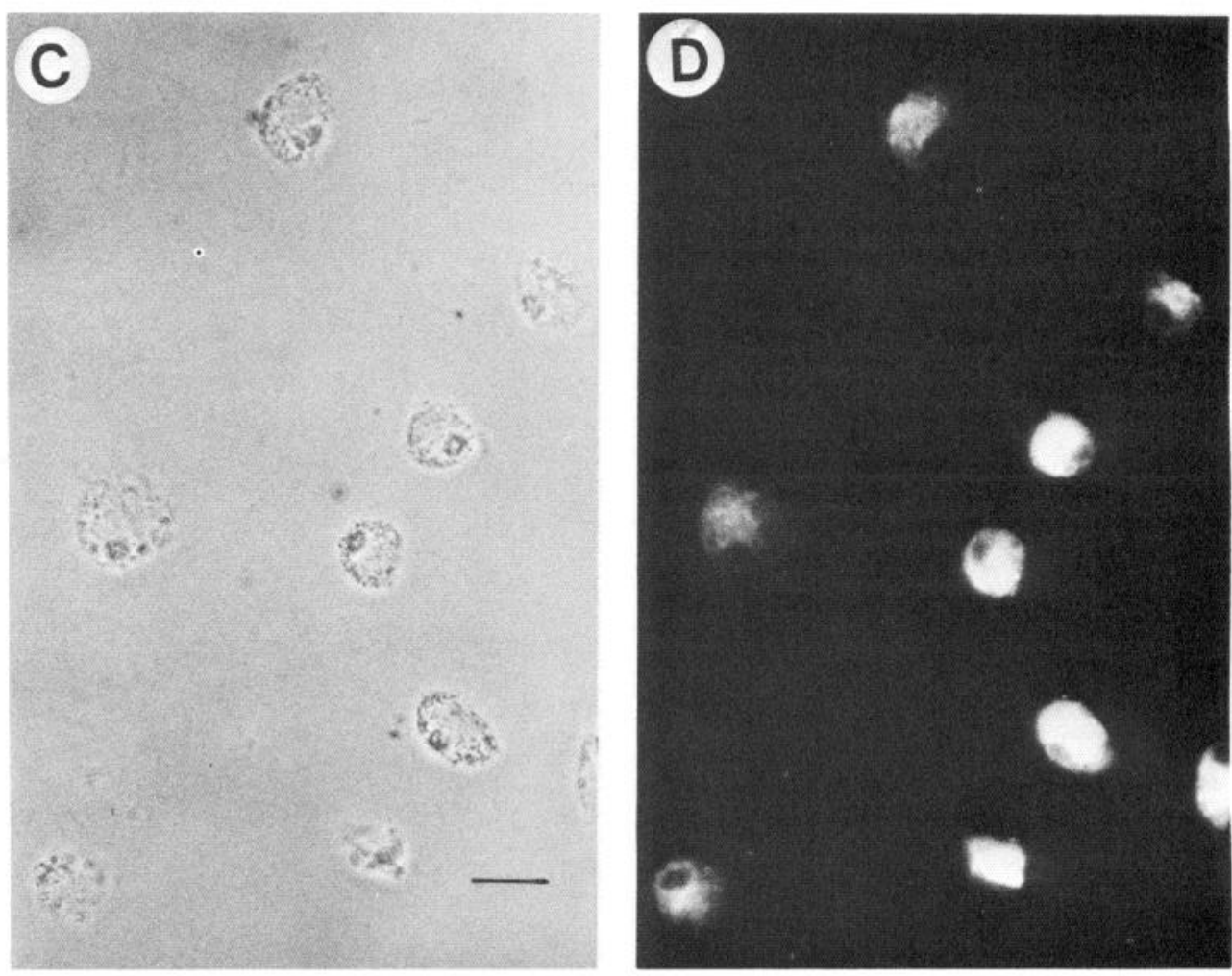

$70 \%$ recovery of all ameboid microglia found in starting cultures of dissociated brain cells. This "cold-shake" technique, however, did not yield enriched populations of oligodendroglia or astroglia.

\section{Histochemical properties of ameboid microglia}

As reported by other investigators, ameboid microglia found in both spinal cord and brain have several morphologic or func- tional properties in common with macrophages (Brierley and Brown, 1982; Ling, 1981; Matsumoto and Ikuta, 1985; Oehmichen, 1983; Raff et al., 1979; Torvik, 1975). We found that freshly isolated ameboid microglia engulfed $5 \mu \mathrm{m}$ latex beads or fixed Staphylococcus aureus within $60 \mathrm{~min}$ at $37^{\circ} \mathrm{C}$ (Table 3); the cells contained the macrophage surface antigens MAC-1 and MAC-3 (Table 3). Ameboid microglia, unlike astroglia or oligodendroglia, had the acetylated low-density lipoprotein recep- 

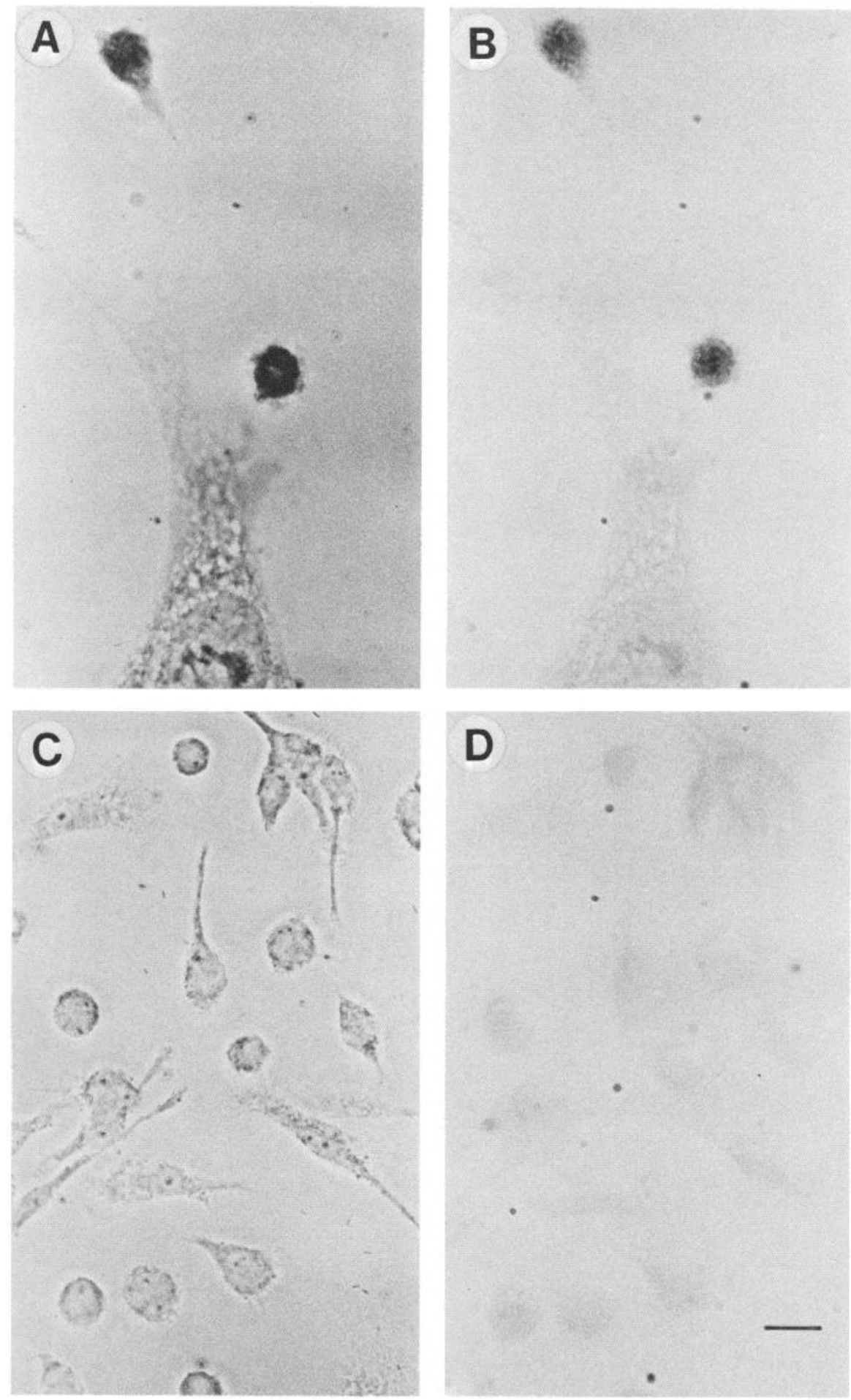

Figure 4. Peroxidase activity was not found in populations of isolated ameboid microglia. $A$ and $B$, Adherent spleen cell cultures from newborn rat after 1 week in culture contained peroxidase $(+)$ macrophages, as shown by a dark reaction product in the brightfield photomicrographs. Fibroblasts, which represented $20 \%$ of adherent spleen preparations, were peroxidase (-). $C$ and $D$, All isolated ameboid microglia were peroxidase (-). Bar, $25 \mu \mathrm{m}$. tor, as demonstrated by the fluorescent probe DIL-ac-LDL (Fig. 3 ). The use of this probe proved to be a more convenient and reliable way to identify ameboid microglia in dissociated brain cell cultures than histochemical staining for nonspecific esterase. Although phagocytic spleen cells and monocytes were peroxidase $(+)$, isolated ameboid microglia were peroxidase $(-)$ (Fig. 4).

\section{Microglia and astroglia in culture}

About $5 \%$ of all cultured cells from newborn rat brain were DILac-LDL(+) microglia (Fig. 3). We often observed ameboid mi- croglia atop GFAP(+) astroglia, suggesting that microglia might be present in enriched preparations of astroglia. We found that astroglia cultures, prepared by the methods of McCarthy and de Vellis (1980), Federoff (1983), or others (Kimelberg, 1983), contained between 2 and $10 \%$ microglia, as shown by the markers DIL-ac-LDL (Fig. 5) or nonspecific esterase. Using a lysosomotrophic agent, L-leucine methyl ester (Thiele et al., 1983), we attempted selective cell-killing to eliminate microglia from cultures of brain. L-leucine methyl ester specifically reduced the numbers of microglia in mixed cultures containing $\operatorname{GFAP}(+)$ astroglia and $\mathrm{GC}(+)$ oligodendroglia (Fig. 6). The lysosomo- 
A

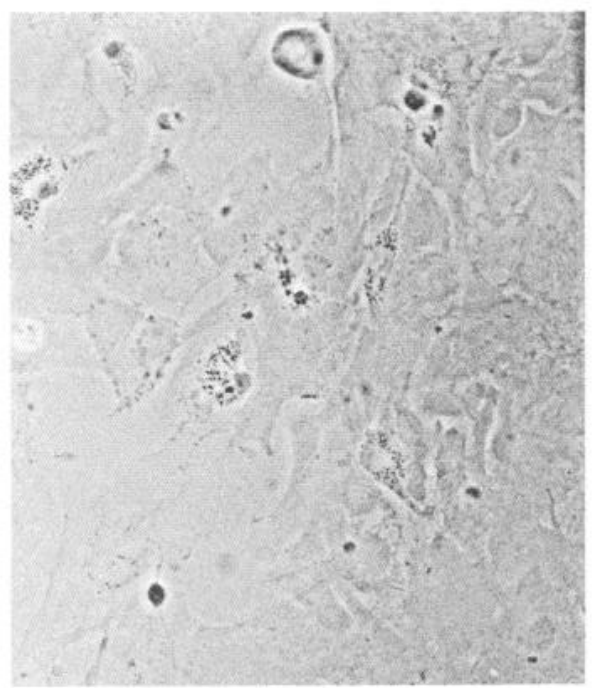

C

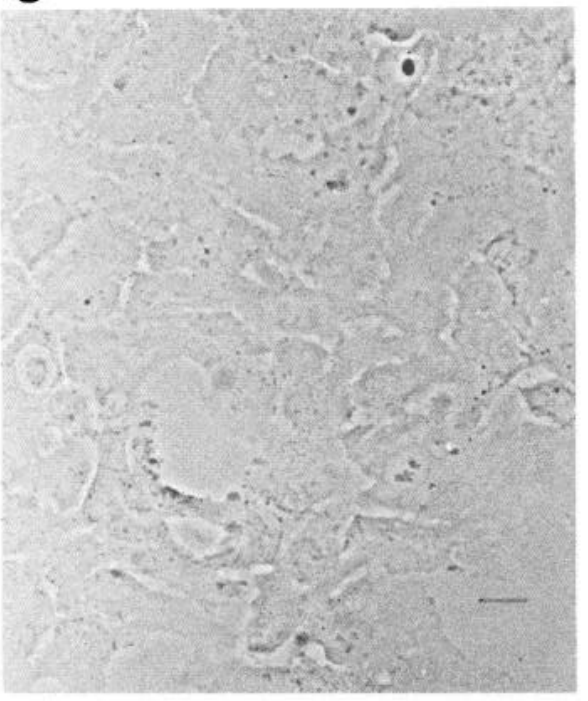

B

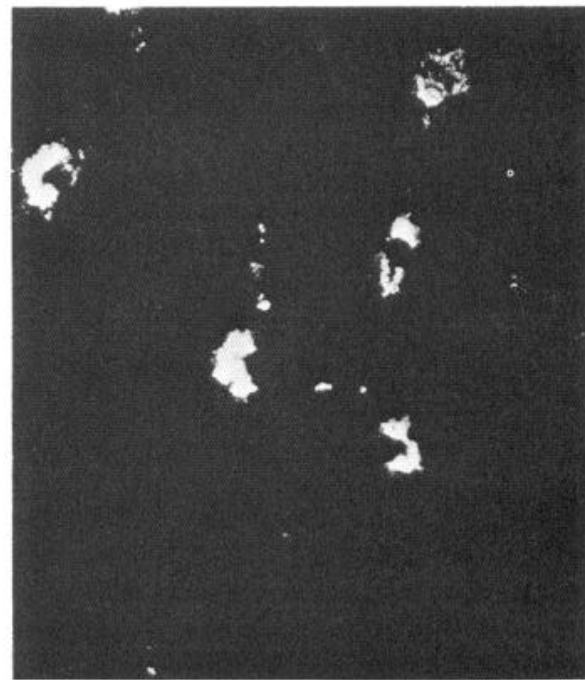

D

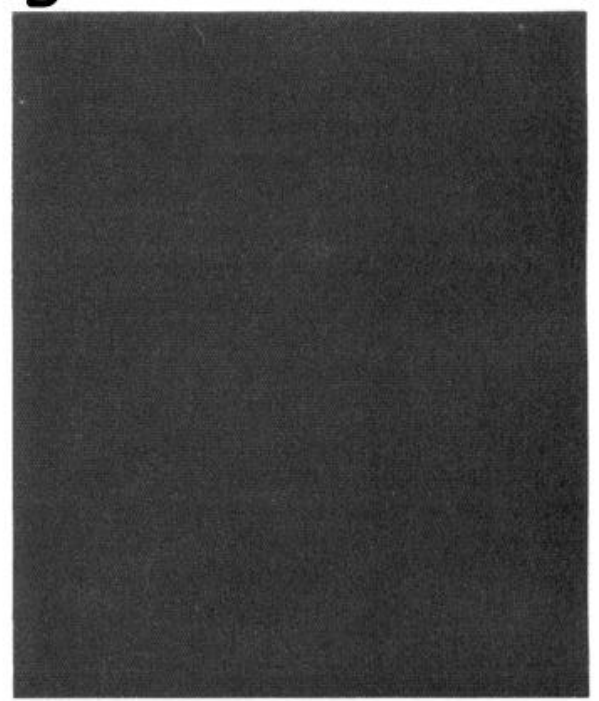

Figure 5. Presence of ameboid microglia in "enriched" astroglial preparations. Enriched cultures of astroglia contained $2-8 \%$ of DIL-ac-LDL $(+)$ ameboid microglia $(B)$. Following treatment with a $5 \mathrm{~mm}$ L-leucine methyl ester, astroglial cultures had few ameboid microglia $(D)$. Bar, 25 $\mu \mathrm{m}$. injured brain (Giulian and Lachman, 1985a). We found that isolated microglia release an $18 \mathrm{kDa}$ IL-1-like peptide when incubated with such macrophage activators as fixed Staphylococcus aureus or lipopolysaccharide (Table 5). Further study, using anion exchange chromatography, showed that this microglial peptide co-eluted with rat macrophage IL-1 and could be neutralized with a murine IL-1-specific antiserum (Giulian, in press). Because IL-1 stimulates astroglial proliferation in vitro (Giulian and Lachman, 1985a), it is reasonable to suggest that ameboid microglia, under certain conditions, help to control astroglial proliferation in vivo by the release of peptides.

\section{Morphology of isolated ameboid microglia}

Twenty-four hours after isolation, ameboid microglia show a vacuolated cytoplasm and circular shape, with diameters ranging from 20-30 $\mu \mathrm{m}$ when placed upon glass coverslips (Fig. 7). Although the light-microscopic appearance of freshly isolated ameboid cells and macrophages were nearly identical, differences between these cell populations were evident using scanning electron microscopy (SEM). Macrophages isolated from the spleen or peritoneum of newborn rats had characteristic
IL-1 is an immunomodulator that stimulates proliferation of lymphocytes and fibroblasts (Dinerallo, 1984). It helps mediate the inflammatory response and has recently been detected in when stimulated by PMA, also released significant quantities superoxide anion (Table 4). The release of this cytotoxin by ameboid cells suggests one mechanism by which microglia might 


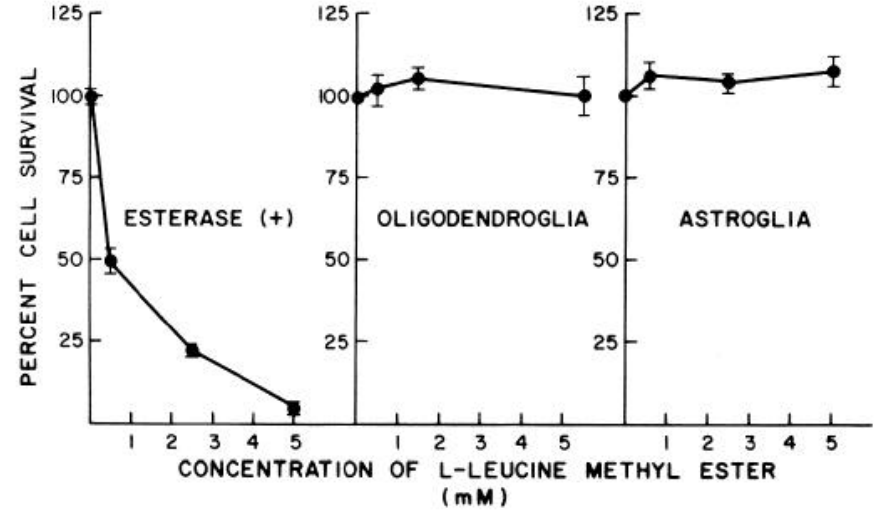

Figure 6. Effects of L-leucine methyl ester upon glial cells. Mixed cell populations were incubated for $2 \mathrm{hr}$ in chemically defined medium containing increasing concentrations of $\mathrm{L}$-leucine methyl ester. GFAP( + ) astroglia, $\mathrm{GC}(+)$ oligodendroglia, or nonspecific esterase $(+)$ microglia were identified $48 \mathrm{hr}$ after treatment. Data were expressed as mean percentage of cell survival \pm SE (bars) when compared to matching, untreated control cultures. At least 3 cultures were used to determine each data point. As is shown, increasing concentrations of L-leucine methyl ester selectively destroyed ameboid microglia.

ruffled edges (Fig. 8; Sone et al., 1981). In contrast, ameboid microglia had multiple short spinous processes which remained on cell surfaces well beyond $96 \mathrm{hr}$ after isolation (Fig. 8). The surface morphology we report here for ameboid cells is identical to that described by Ling and co-workers (1983) for migrating microglia found in tissue culture. Moreover, our isolated cells show the same surface features associated with microglia in developing brain (Tseng et al., 1983). SEM also confirmed the
Table 3. Properties of ameboid microglia, adherent spleen cells, and peritoneal macrophage

\begin{tabular}{llll} 
& $\begin{array}{l}\text { Ameboid } \\
\text { microglia }\end{array}$ & $\begin{array}{l}\text { Adherent } \\
\text { spleen cells }\end{array}$ & $\begin{array}{l}\text { Peritoneal } \\
\text { macrophage }\end{array}$ \\
\hline Nonspecific esterase & +++ & +++ & +++ \\
Peroxidase & - & +++ & -+ \\
MAC-1 & +++ & +++ & +++ \\
MAC-3 & +++ & +++ & ++ \\
DIL-ac-LDL & +++ & +++ & +++ \\
Phagocytosis $^{a}$ & +++ & +++ & +++ \\
Proliferation $^{b}$ & +++ & - & - \\
GFAP & - & - & - \\
GC & - & - & -
\end{tabular}

Ameboid microglia, resident peritoneal macrophages, and adherent spleen cells were isolated from newborn rat. Properties of cells were examined after $3 \mathrm{~d}$ in culture.

${ }^{a}$ Engulfment of fixed Staphylococcus aureus and latex microspheres $5 \mu \mathrm{m}$ in diameter after $60 \mathrm{~min}$ at $37^{\circ} \mathrm{C}$.

${ }^{b}$ Monitored by the appearance of mitotic cells and increase in cell number.

homogeneity of the enriched microglia preparations, for there was no evidence of macrophages or fibroblasts. Highly branched oligodendroglia were the major contaminating cells (15-20\% of the total population) found after the first adhesion step with the "warm-shake" technique (Table 1); these contaminating cells were virtually absent after the second adhesion step.

\section{Proliferation of ameboid microglia}

In general, after $5 \mathrm{~d}$ in culture, ameboid cells thrived, whereas peritoneal or spleen macrophages showed limited survival. Within $48 \mathrm{hr}$ after isolation, binucleated ameboid cells were

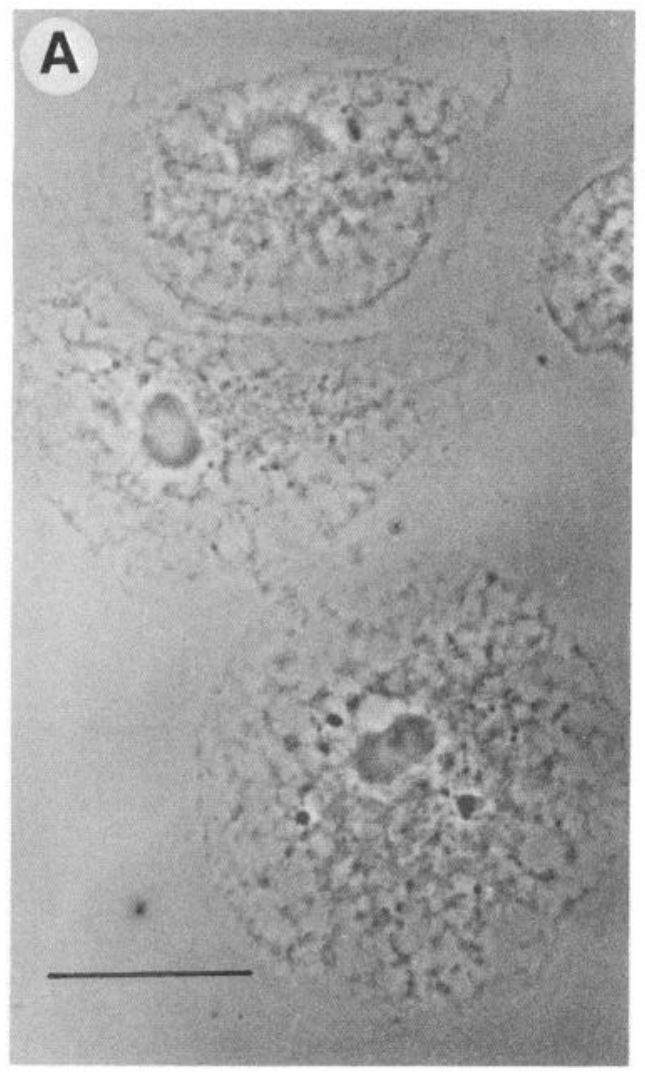

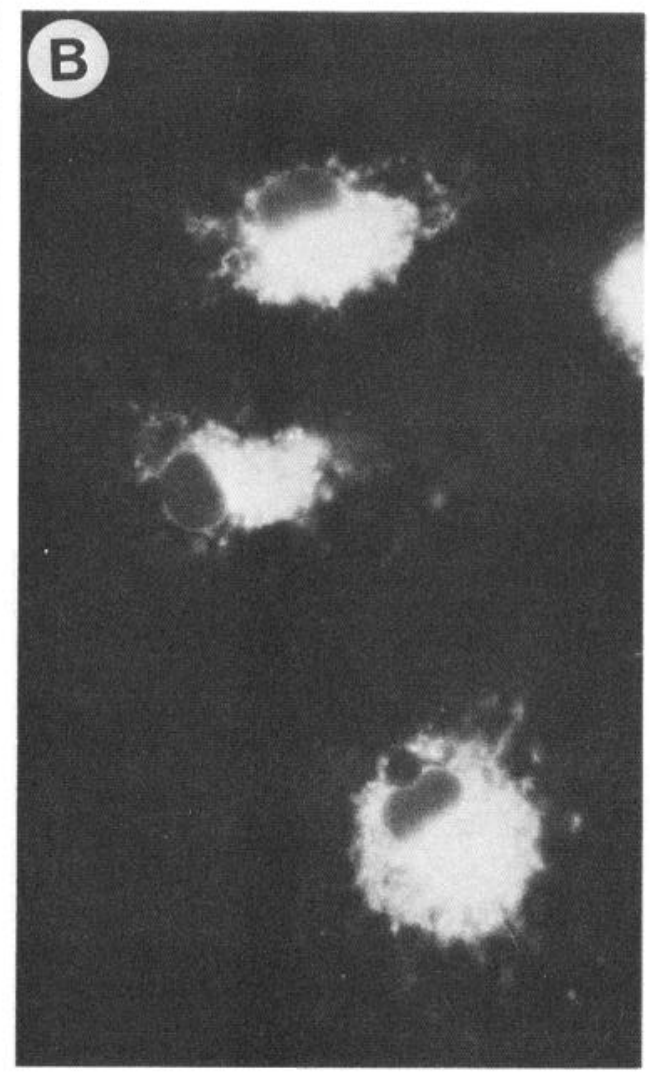

Figure 7. (A) Phase photomicrograph of ameboid microglia $24 \mathrm{hr}$ after isolation. $(B)$ When plated upon glass coverslips, DIL-ac-LDL(+) cells had vacuolated cytoplasm. Bar, $20 \mu \mathrm{m}$. 

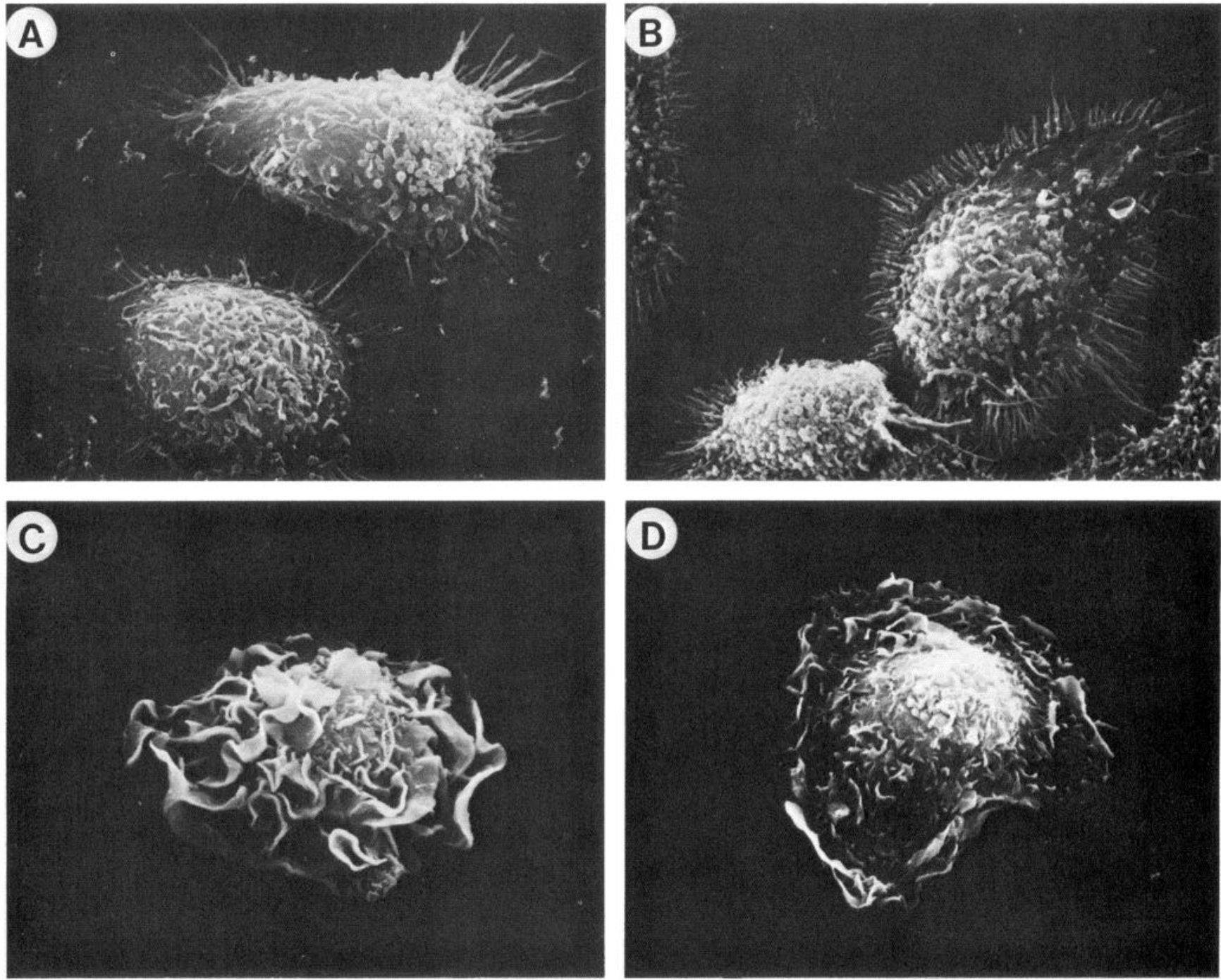

Figure 8. Scanning electron photomicrographs showing the morphology of isolated ameboid microglia and spleen macrophages from newborn rat after $1(A$ and $C)$ and $4(B$ and $D)$ d in culture. Ameboid microglia $(A$ and $B)$ had numerous spinous processes that persisted throughout the culture period, whereas macrophages $(C$ and $D$ ) had characteristic ruffled edges. Spinous processes have been described on the surface of ameboid microglia found in newborn rat brain (Ling et al., 1983). Bar, $10 \mu \mathrm{m}$

often observed with occasional telophase pairs and mitotic figures present; these dividing cells were nonspecific esterase $(+)$ and DIL-ac-LDL(+) (Fig. 9).

We quantitated ameboid cell proliferation for the first $60 \mathrm{hr}$ after isolation by monitoring the number of microglia grown in

\section{Table 4. Release of superoxide anion}

\begin{tabular}{llcl} 
& \multicolumn{2}{l}{$\begin{array}{l}\text { Released superoxide anion } \\
\left(\mathrm{nmol} / \mathrm{min} / \text { cell } \times 10^{-7}\right)\end{array}$} & \\
\cline { 2 - 3 } & $\begin{array}{l}\text { PMA- } \\
\text { stimulated }\end{array}$ & $\begin{array}{l}\text { Control } \\
\text { Fold } \\
\text { increase }\end{array}$ \\
\hline Peritoneal macrophage & $18 \pm 3$ & $4 \pm 2$ & 4.4 \\
Ameboid microglia & $92 \pm 5$ & $36 \pm 3$ & 2.5
\end{tabular}

Enriched cultures of newborn rat microglia or resident peritoneal macrophage $(500,000$ cells in $35 \mathrm{~mm}$ dishes) were grown in $1.5 \mathrm{ml}$ defined medium for $48 \mathrm{hr}$ and then incubated with phorbol myristate acetate (PMA) for $90 \mathrm{~min}$ and assayed for the release of superoxide anion, as described in Materials and Methods (Johnston, 1981). Each data point represents the mean value \pm SE from five cultures. Both types of cells showed induced release of superoxide anion. defined medium with or without $10 \%$ fetal calf serum. As shown in Figure 10, calf serum promoted cell proliferation. Increasing numbers of DIL-ac-LDL $(+)$ microglia were also found in mixed cell cultures of rat brain over a 2 week period (data not shown).

\section{Table 5. Release of Interleukin-1}

\begin{tabular}{lc} 
Cell activator & $\begin{array}{c}{ }^{3} \mathrm{H} \text {-thymidine incorporation } \\
\text { by thymocytes }(\mathrm{cpm})\end{array}$ \\
\hline S. aureus & $7262 \pm 111$ \\
LPS & $6300 \pm 200$ \\
Control & $555 \pm 95$ \\
Untreated & $620 \pm 40$
\end{tabular}

Production of IL-1 by enriched microglial populations in vitro. One hundred and fifty thousand cells were incubated in $1.5 \mathrm{ml}$ defined medium containing lipopolysaccharide (LPS; $5 \mu \mathrm{g} / \mathrm{ml}$ culture medium), fixed $S$. aureus $(10 \mu \mathrm{l}$ suspension/ $\mathrm{ml}$ culture medium), or $10 \mu \mathrm{l}$ PBS (control) for $24 \mathrm{hr}$. The media conditioned by these cells were monitored for release of IL-1 using the mouse thymocyte assay (Giulian and Lachman, 1985a). We confirmed the microglial secretion product as IL-1 both by co-elution with authentic rat macrophage IL-1, using anion exchange chromatography, and by neutralization with a murine-specific anti-IL-1 serum (Giulian, in press). 
A

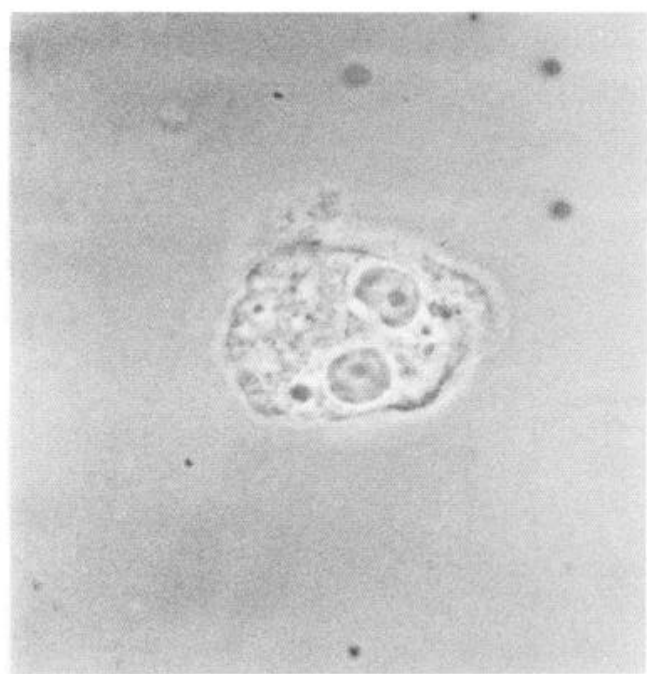

C

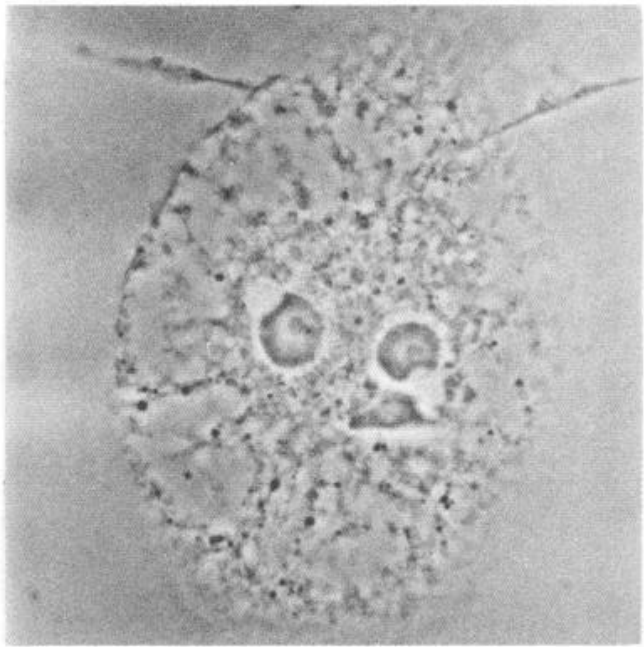

E

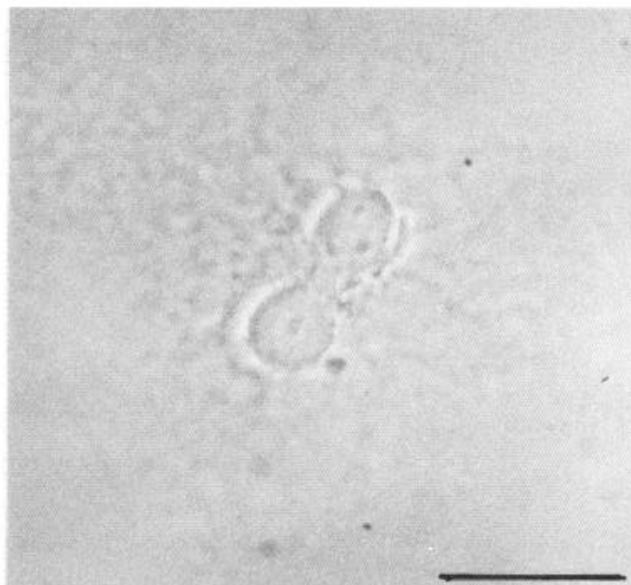

B

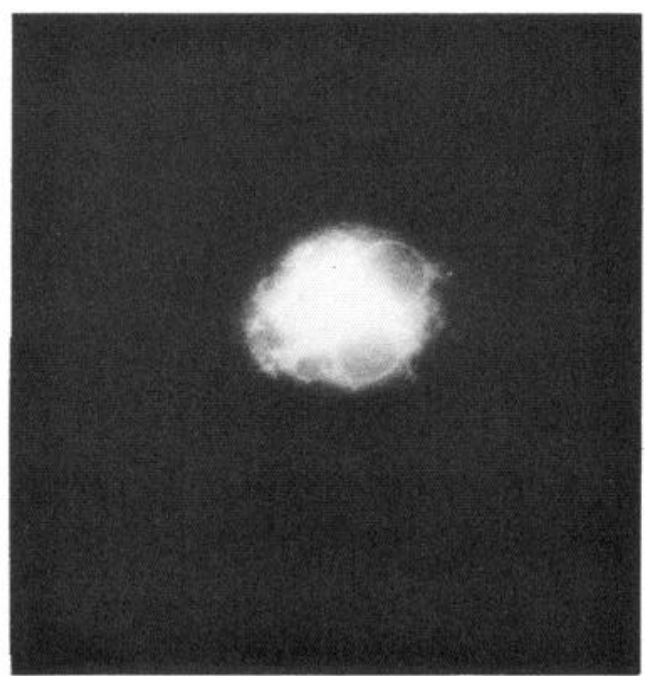

D

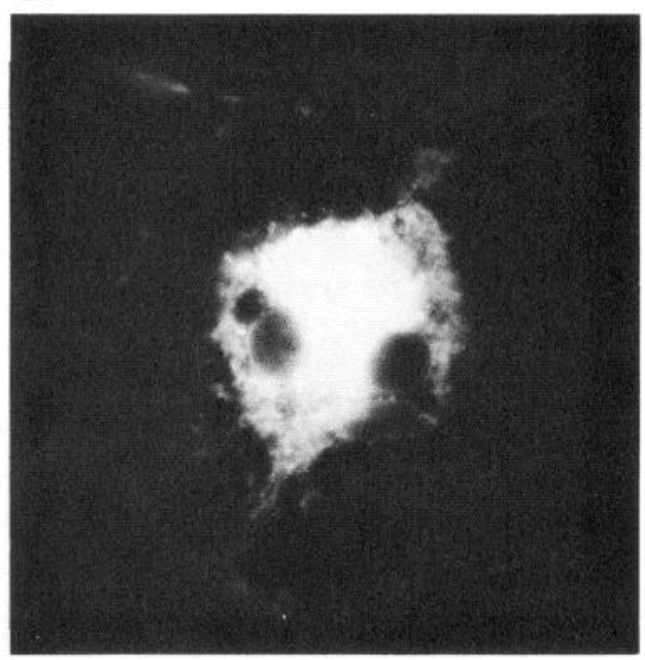

F

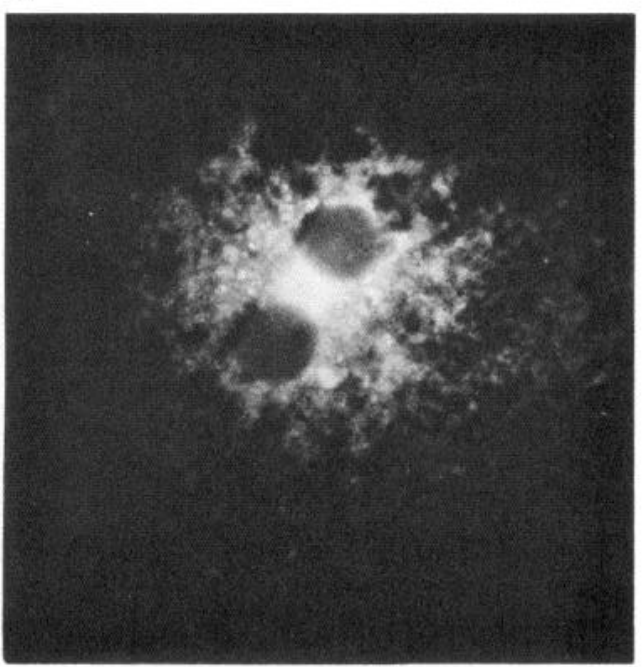

Figure 9. Phase photomicrographs of proliferating ameboid microglia. Cells were grown in defined medium with $10 \%$ fetal calf serum. Within 48 $\mathrm{hr}$ after plating, binucleated cells and mitotic figures were noted $(E$ and $F)$. All proliferating cells were DIL-acLDL (+). Bar, $20 \mu \mathrm{m}$. 


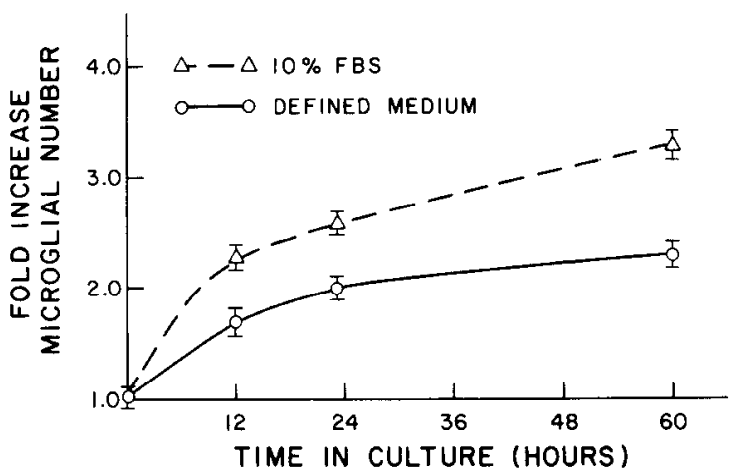

Figure 10. Proliferation of ameboid microglia in the presence or absence of fetal calf serum. Two hundred thousand were placed on glass coverslips in $35 \mathrm{~mm}$ dishes containing $1.5 \mathrm{ml}$ defined medium with or without $10 \%$ fetal calf serum. Data are expressed as the mean fold of increase in number of ameboid microglia found at the time of plating.

Since these findings suggested that mitogens might stimulate proliferation of microglia, we tested the effects of IL-3, a mitogen for monocytic stem cells (Lee et al., 1982; Metcalf, 1985), upon ameboid cells. Partially purified IL-3 from the WEHI- 3 cell line increased the number of microglia five-to sevenfold when grown in defined medium over a $72 \mathrm{hr}$ period (Fig. 11). Ameboid cells incubated for $24 \mathrm{hr}$ with 250 units of IL-3 also showed a 2- to 3-fold increase in the incorporation of ${ }^{3} \mathrm{H}$-thymidine (data not shown). Finally, recombinant IL-3 stimulated proliferation of ameboid microglia, though not macrophages, isolated from newborn rat (Table 6).

To summarize, ameboid microglia have properties in common with other classes of phagocytic mononuclear cells. However, surface morphology, peroxidase activity, and proliferative capacity indicate that ameboid microglia represent a population of cells distinct from monocytes, adherent spleen cells, or resident peritoneal macrophages.

\section{Differentiation of ameboid microglia into process-bearing cells}

Rio-Hortega (1932) believed that the differentiation of ameboid microglia is marked by a loss of macrophage-like properties and the growth of thin cytoplasmic projections. It is widely believed that ameboid cells transform into ramified cells during normal brain development (Ling, 1981; Oehmichen, 1983). Other investigators have shown that the number of ameboid microglia found in rodent brain declines by the second week of postnatal life, with a concurrent increase in the number of ramified mi-

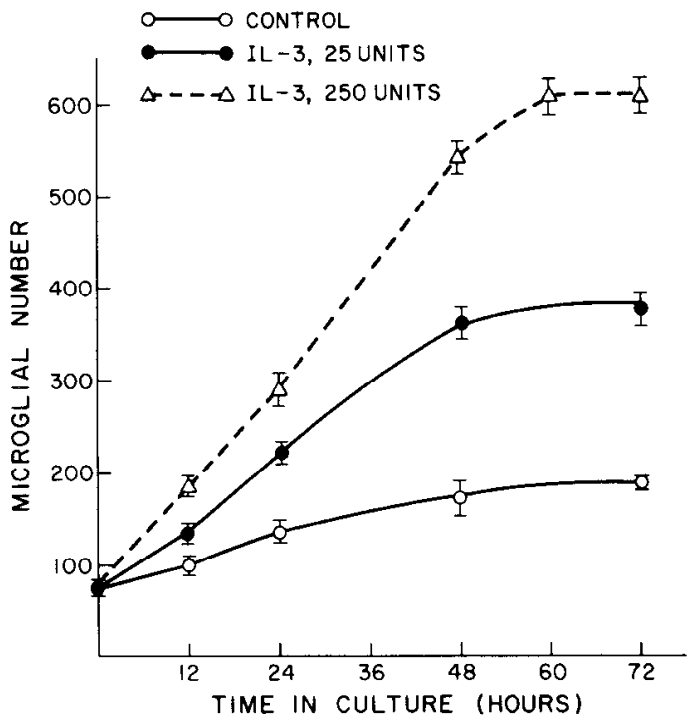

Figure 11. Proliferation of ameboid microglia grown in chemically defined medium in increasing concentrations of partially purified IL-3 from the WeHI-3 cell line. Data are expressed as mean cell number/ $\mathrm{mm}^{2} \pm \mathrm{SE}$.

croglia (Boya et al., 1979; Ling, 1981; Murabe and Sano, 1982; Stensaas and Reichart, 1971).

After several days in culture, we observed that a few of the isolated ameboid cells hegan to develop thin cytoplasmic projections. These "process-bearing" cells showed either a complex multipolar pattern (Fig. $12 ;<2 \%$ of the total cell population) or, more commonly, a uni- or bipolar morphology (Fig. 13; $<7 \%$ of total cells). One-week-old process-bearing cells were nonspecific esterase(+), DIL-ac-LDL $(+), \operatorname{GFAP}(-)$, and GC( $(-)$ and were easily distinguished by phase microscopy from ameboid microglia or cultured macrophages (Figs. 11 and 13). The ability of ameboid microglia to form cytoplasmic projections in vitro sugested a morphologic differentiation similar to that thought to occur in vivo.

We tested the effects of DMSO and retinoic acid-agents known to accelerate differentiation of cultured cells (Jones-Villeneuve et al., 1982; Wang et al., 1985)-upon isolated ameboid microglia. Within $48 \mathrm{hr}$ of incubation with these agents, we found a significant increase in the number of cells with long, thin processes (Table 7). For purposes of quantitation, we defined a "process-bearing" microglia as a cell with at least one thin process extending a distance greater than three times the
Table 6. Effects of recombinant Interleukin-3 upon cell proliferation

Fold increase in cell number

\begin{tabular}{ll}
\hline Ameboid microglia & $4.0 \pm 0.3$ \\
Adherent spleen cells & $1.0 \pm 0.3$ \\
Peritoneal macrophage & $0.8 \pm 0.1$
\end{tabular}

Murine IL-3, multipotential colony-stimulating factor, promotes proliferation and differentiation of monocytic precursor cells (Lee et al., 1982; Metcalf, 1985). Two hundred thousand cells were grown in $1.5 \mathrm{ml}$ of defined medium for $72 \mathrm{hr}$, in the presence of $20 \mu \mathrm{l}$ recombinant IL-3 or $20 \mu \mathrm{l}$ PBS. Ameboid microglia and the other mononuclear phagocytic cells from postnatal rat were identified by the fluorescent probe DIL-ac-LDL. Data were expressed as the mean fold of increase in cell number + SE in cultures incubated with IL-3 as compared to contro cultures. Cell numbers were determined from 10 randomly selected microscopic fields $\left(0.314 \mathrm{~mm}^{2}\right)$ using at least 5 cultures for each experimental group.
Table 7. Induction of morphologic differentiation in ameboid microglia

\begin{tabular}{lr} 
Culture conditions & \multicolumn{1}{l}{$\begin{array}{l}\text { Process-bear } \\
(\%)\end{array}$} \\
\hline Untreated & $8.2 \pm 1.1$ \\
$0.7 \%$ Ethanol & $7.9 \pm 1.8$ \\
$1.0 \%$ DMSO & $41.1 \pm 5.3$ \\
$0.1 \mu \mathrm{M}$ Retinoic acid & $44.1 \pm 4.0$
\end{tabular}

Freshly isolated ameboid microglia were incubated for $48 \mathrm{hr}$ with $0.7 \%$ ethanol, $1.0 \%$ DMSO, or $0.1 \mu \mathrm{M}$ retinoic acid. Cells in the presence of DSMO or retinoic acid send out long, thin processes. Those cells with projections greater than 3 times the cell body diameter were classified as process-bearing. Retinoic acid, dissolved in $100 \%$ ethanol, gave the culture medium a final ethanol concentration of $0.5 \%$. 


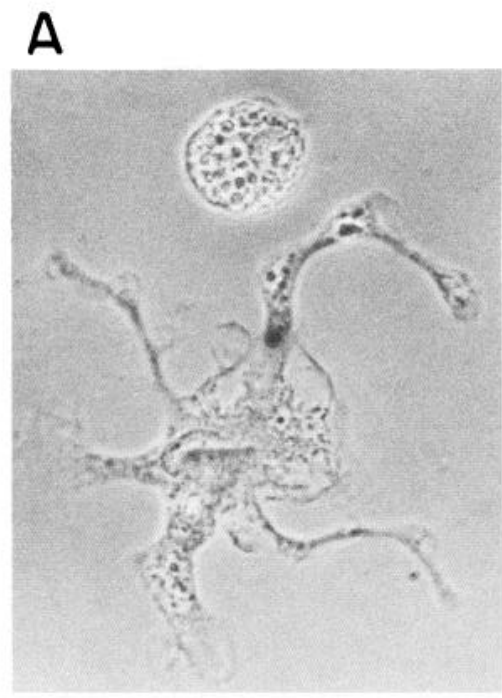

C

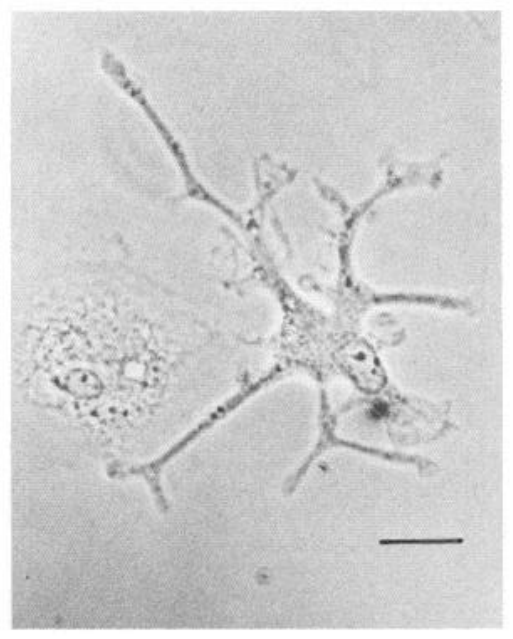

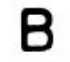

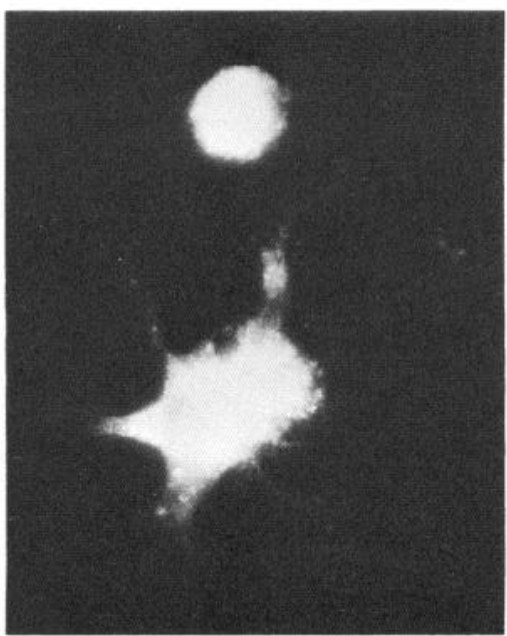

D

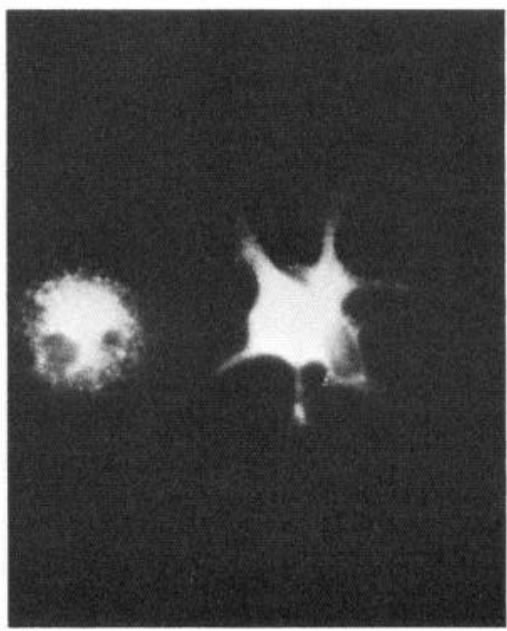

Figure 12. Photomicrographs of DIL-ac-LDL(+) microglia undergoing transformation into multipolar cells. Cells were grown in $10 \%$ fetal calf serum for $5 \mathrm{~d}$. Both ameboid and multipolar cells were DIL-ac-LDL(+). Bar, $20 \mu \mathrm{m}$. cell body's diameter (usually more than $80 \mu \mathrm{m}$; Figs. 13 and 14). Most of the process-bearing microglia that appeared after incubation with retinoic acid or DMSO contained a major projection with an occasional short, secondary branch. The projections were 1.0 to $1.5 \mu \mathrm{m}$ in diameter, although they appeared to flatten out in areas that contained vacuoles and ac-LDL receptors. SEM showed a cluster of short, spinous projections along the cell body and at branch terminals (Fig. 14).

\section{Table 8. Phagocytic activity of ameboid and process-bearing microglia}

\begin{tabular}{lll} 
& $\begin{array}{l}\text { Ameboid cells } \\
(\%)\end{array}$ & $\begin{array}{l}\text { Process-bearing } \\
\text { cells (\%) }\end{array}$ \\
\hline \% Cells containing beads & $95.2 \pm 4.3$ & $18.1 \pm 5.5$ \\
Beads per cell & $4.9 \pm 0.3$ & $0.6 \pm 0.2$
\end{tabular}

Cells in $1.5 \mathrm{ml}$ medium were exposed to $5 \mu \mathrm{m}$ latex beads $(20 \mu \mathrm{l}$ of $25 \% \mathrm{vol} / \mathrm{vol}$ suspension) for $90 \mathrm{~min}$ at $37^{\circ} \mathrm{C}$. Scores were mean values $\pm \mathrm{SE}$, based upon randomly selected cells with ameboid or branching morphology. The processbearing cells were those that contained at least one process greater than 3 cell body diameters. Data were obtained for 5 cultures treated with $1 \%$ (vol/vol) DMSO for $48 \mathrm{hr}$ prior to incubation with latex beads.

\section{Properties of process-bearing microglia}

We compared macrophage-associated properties of ameboid and process-bearing microglia. Ameboid cells, despite prolonged periods in vitro, retained nonspecific esterase activity and DIL-acLDL binding. In contrast, process-bearing microglia showed a gradual loss of nonspecific esterase activity and DIL-ac-LDL binding by 3 weeks in culture, as well as a reduction in phagocy-

\section{Table 9. Properties of ameboid and process-bearing microglia}

\begin{tabular}{lll} 
& Ameboid cells & $\begin{array}{l}\text { Process- } \\
\text { bearing cells }\end{array}$ \\
\hline Nonspecific esterase $(+)$ & +++ & +- \\
DIL-ac-LDL(+) & +++ & +- \\
Phagocytosis & +++ & +- \\
Proliferation & +++ & -
\end{tabular}

A comparison of cell properties found in ameboid and process-bearing microglia. After 3 weeks in culture phagocytosis, nonspecific esterase activity and DIL-acLDL receptors were gradually lost in process-bearing cells but persisted in ameboid cells. Process-bearing cells did not proliferate. 

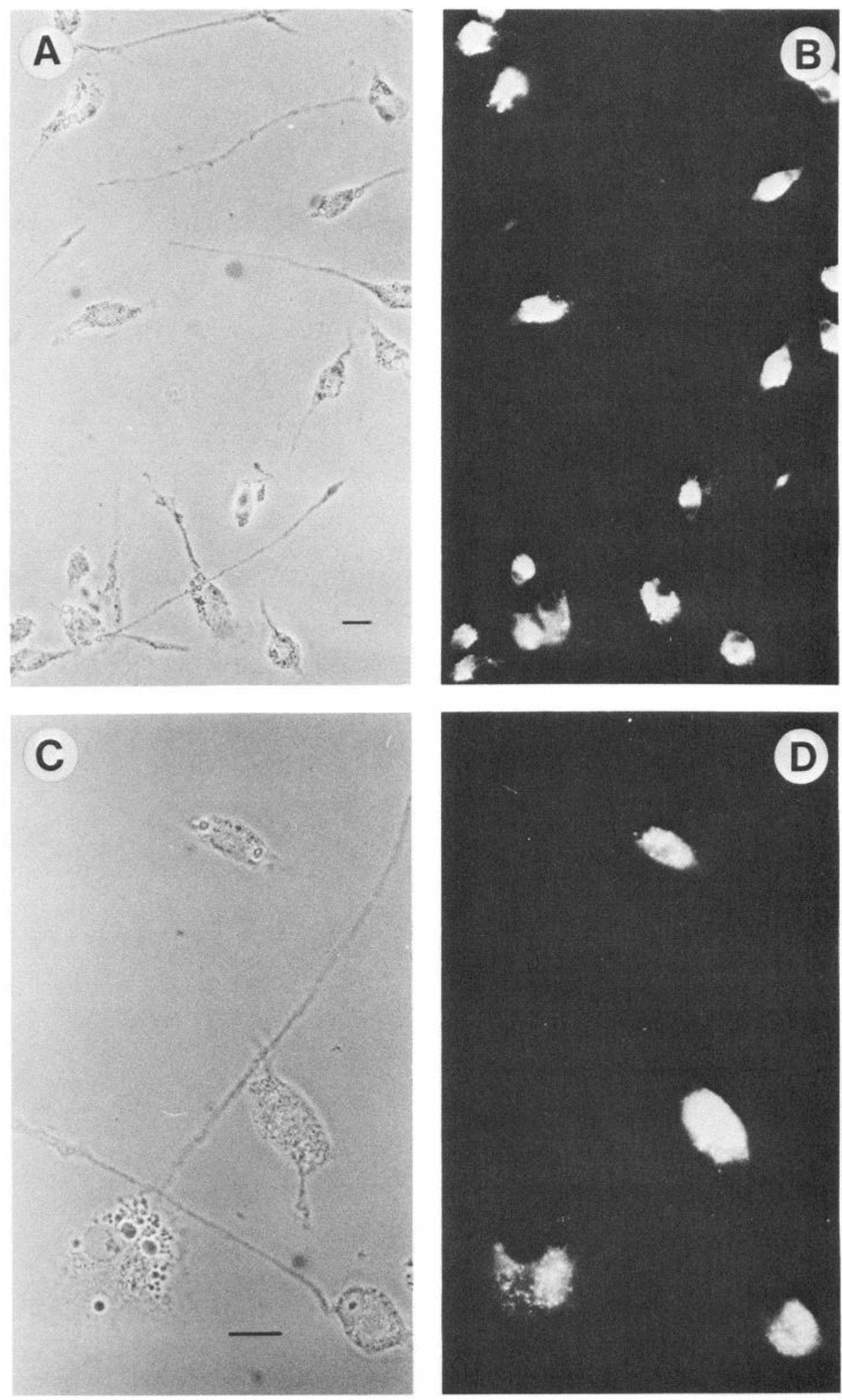

Figure 13. Photomicrographs of ameboid microglia after $72 \mathrm{hr}$ culture with $0.1 \mu \mathrm{M}$ retinoic acid. Processbearing cells retain DIL-ac-LDL binding and show long, thin cytoplasmic projections. Bar, $20 \mu \mathrm{m}$.

tic activity (Fig. 15; Table 8). In addition, although $10-15 \%$ of ameboid cells showed mitotic or binucleated forms, less than $0.1 \%$ of process-bearing cells showed evidence of proliferation. We concluded that process-bearing cells eventually lose macrophage-associated properties in vitro, as well as the ability to proliferate (Table 9). These changes are similar to those thought to occur in vivo as ameboid cells transform into ramified microglia (Ling, 1981).

\section{Discussion}

Although microglia have long been considered important intrinsic cells of the brain, characterization of their cellular or 

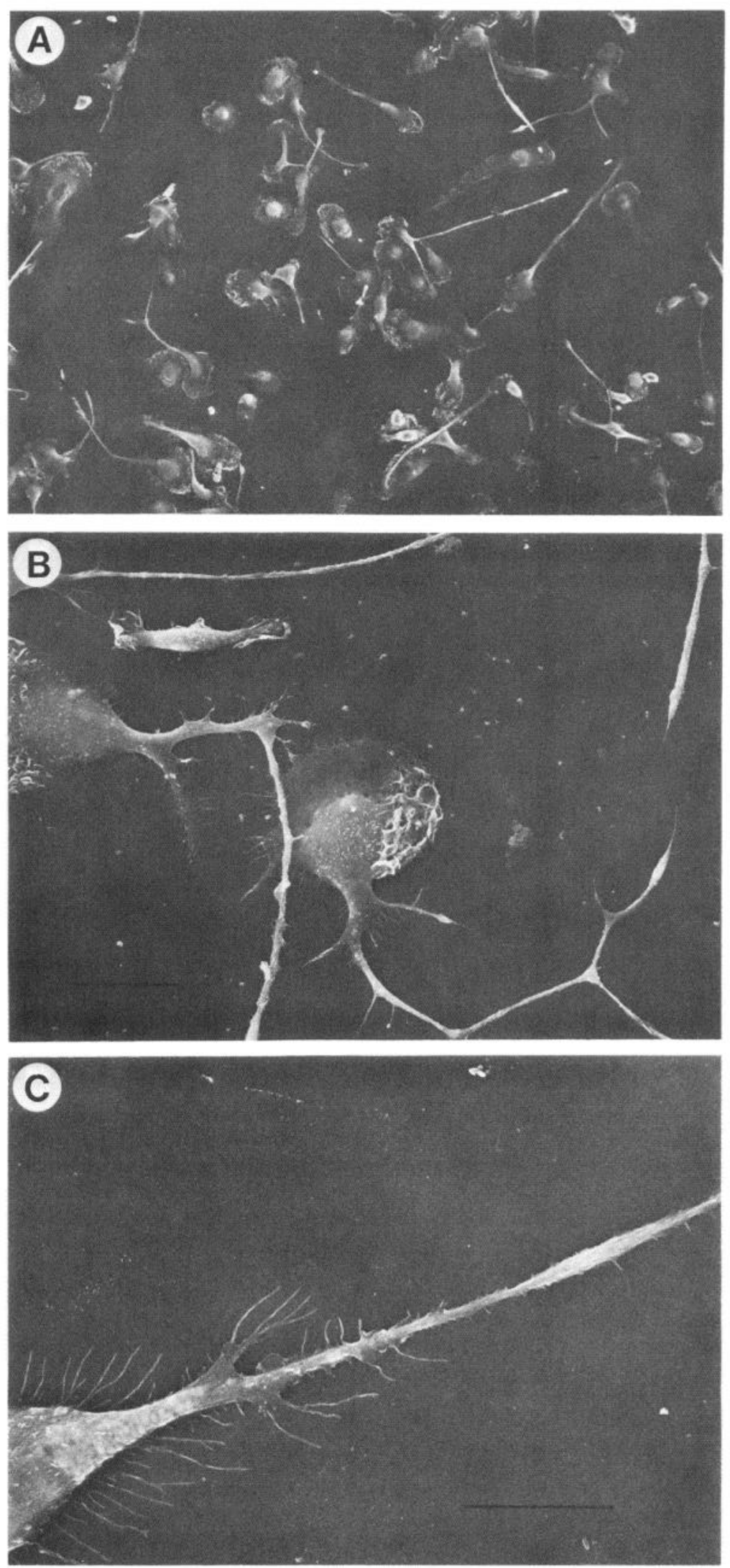

Figure 14. Scanning electron photomicrographs of process-bearing microglia grown for $7 \mathrm{~d}$ in $1 \%$ DMSO. $A$, The cell population is a mixture of ameboid and process-bearing cells. Thin cytoplasmic projections extend to several hundred microns in length. $B$ and $C$, A variety of cytoplasmic projections (1.0-1.5 $\mu \mathrm{m}$ in diameter) are found among the process-bearing cells. Bar, $10 \mu \mathrm{m}$. biochemical properties has been limited (Ling et al., 1982; Oehmichen, 1983; Raff et al., 1979; Valentino and Jones, 1981). Ling et al. (1983) reported that ameboid microglia adhered to plastic and migrated from tissue fragments in vitro. By exploiting cell adhesion properties, we obtained viable cell cultures containing nearly $95 \%$ ameboid microglia.

We believe that the responses of ameboid microglia to cell activators in vitro imply that there are important functions of 
A
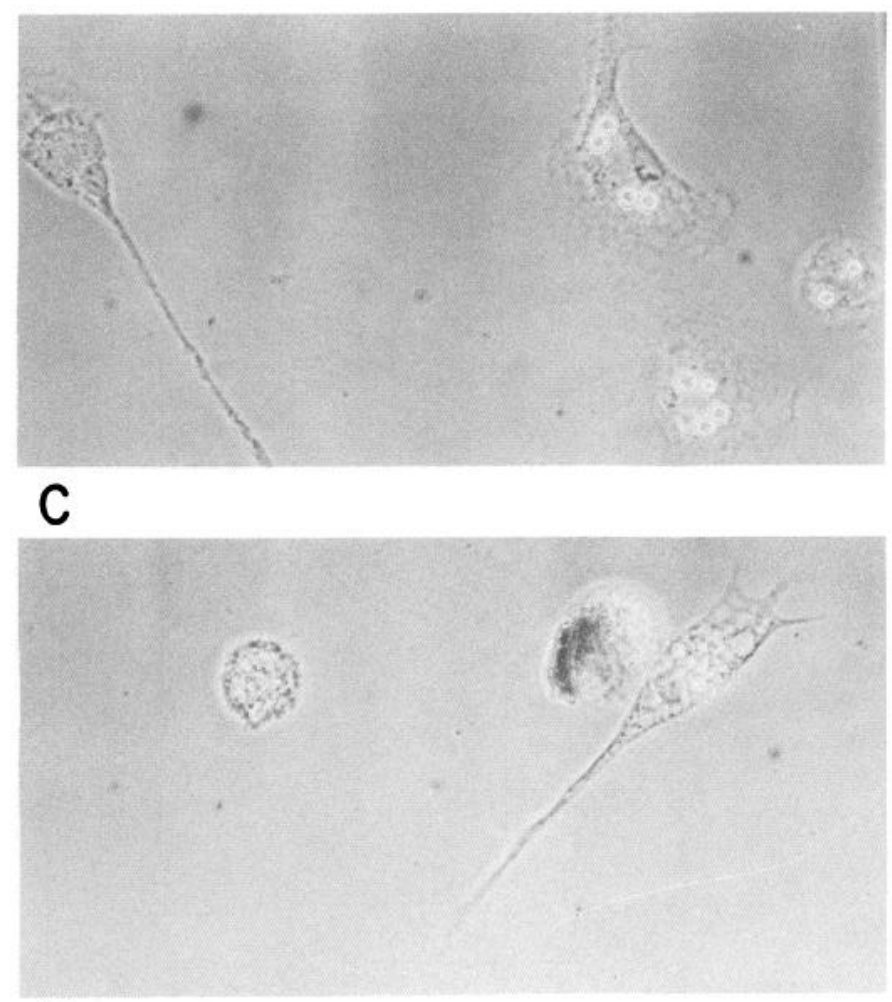

E

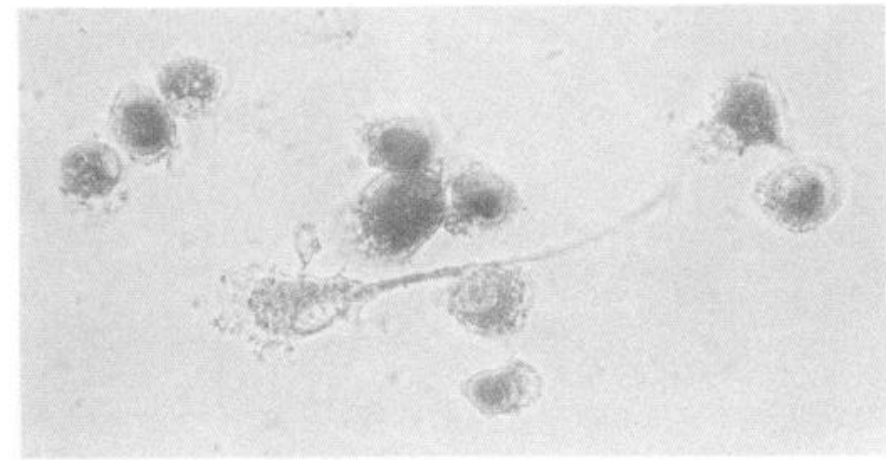

B

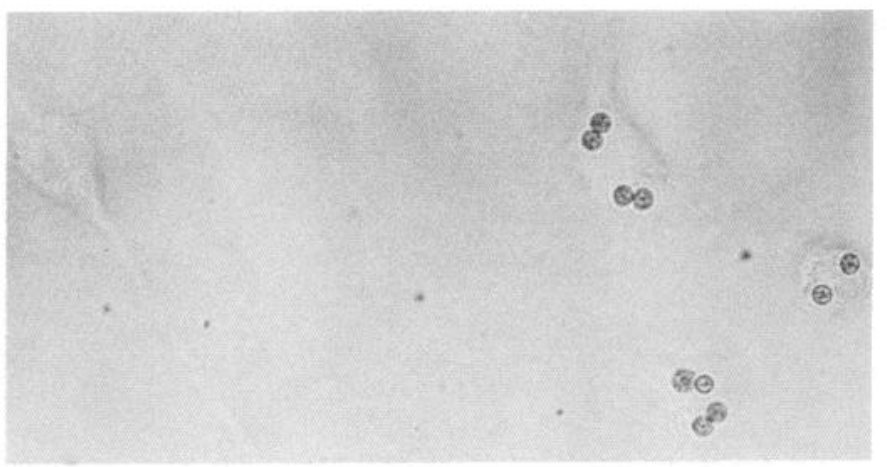

D

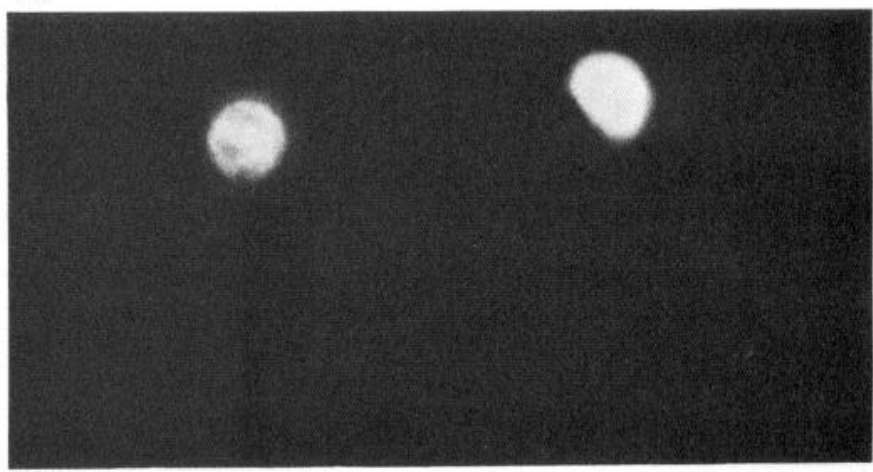

F

Figure 15. Process-bearing microglia lose macrophage-like properties after 3 weeks in culture. Cells were initially treated with $0.1 \mu \mathrm{M}$ retinoic acid for $48 \mathrm{hr}$. Phase photomicrographs $(A, C$, and $E)$ of cells incubated with $5 \mu \mathrm{m}$ latex beads, DIL-ac-LDL, or stained for nonspecific esterase activity. As shown by bright-field photographs, process-bearing cells, in contrast to ameboid cells, did not ingest latex beads $(B)$ and did not show loss of esterase activity $(F)$. Process-bearing cells did not bind DIL-ac-LDL $(D)$. Bar, $20 \mu \mathrm{m}$.

microglia in vivo. For example, soluble factors stimulated microglial proliferation. Perhaps secreted mitogens produced in the CNS control the microglial number in specific regions of the brain during development. It is also possible that lymphokines released by invading lymphocytes help to mediate microglial activity at sites of brain inflammation.

Moreover, the secretion products from ameboid microglia may act as regulators of cellular growth in the brain. We found, for example, that lipopolysaccharide and fixed Staphylococcus aureus stimulated microglia to release IL-1. IL-1, which has been isolated from injured mammalian brain (Giulian and Lachman, 1985b), serves as a mitogen for astroglia. Our laboratory has also found that ameboid microglia release another class of astroglial mitogens, the glial-promoting factors (Giulian, 1984; Giulian and Baker, 1985). Since these peptides have been found in developing and injured CNS, it is possible that microglia control astroglial proliferation in injured or developing neural tissues by a release of growth factors.

A comparison of ameboid microglia with blood monocytes and body macrophages showed a number of similarities in morphology, cellular functions, cell surface antigens, and histochemical properties. SEM demonstrated, however, that isolated microglia had numerous spinous processes that easily distinguished them from spleen and peritoneal macrophages. Moreover, cultured ameboid microglia differed from circulating and tissue-associated mononuclear phagocytes by a lack of peroxidase activity and by an ability to proliferate in vitro. Although none of these properties are unique to microglia [i.e., Kupffer cells proliferate, alveolar macrophages show spinous processes, and bone marrow macrophages are peroxidase $(-)]$, we believe 
ameboid microglia to be a distinct class of phagocytic mononuclear cell (Ogawa et al., 1978; Sone et al., 1981; Widmann and Fahimi, 1976; Wisse, 1977).

By demonstrating that ameboid cells have the capacity to form branches and lose macrophage-associated properties in vitro, we support the model that ameboid cells transform into ramified microglia in vivo (Ling, 1981; Murabe and Sano, 1982). However, we find that not all cells form branches, and that there is a heterogeneity in the morphologies of process-bearing cells. Perhaps the ameboid microglia described here include progenitor cells that differentiate into several subpopulations of glia. Since the role of ramified cells in normal CNS remains unknown, study of cultured microglia may elucidate functional capacities of this type of brain glia.

Although the present work does not seek to determine the origin of microglia, our obscrvations arc compatible with the widely held belief that ameboid microglia arise from monocytic stem cells (Ling, 1981; Oehmichen, 1983; Rio-Hortega, 1932). During embryogenesis, stem cells of mesenchymal origin may enter the CNS and give rise to a population of ameboid cells distinct from that of circulating monocytes or body macrophages. The origin of brain phagocytes after injury is less certain, however (Boya et al., 1979; Konigsmark and Sidman, 1963; Ling, 1981; Torvik, 1975), and may depend upon the type of injury sustained. For example, stab wound injury elicits monocyte invasion, whereas Wallerian degeneration promotes microglial proliferation (Konigsmark and Sidman, 1963; Oehmichen, 1983). Perhaps identification of cell markers that distinguish ameboid microglia from other phagocytic cells will aid in determining the roles of different scavenger cell populations in brain injury.

As first noted by Rio-Hortega (1932), microglia migrate, differentiate, and proliferate during specific periods in development or at sites of brain injury. A characterization of signals that regulate such events may now be possible by employing the isolated cell preparations described here. Co-culture experiments and fractionation of brain tissues may lead to identification of mitogens, chemotactic agents, or differentiation factors that help to control microglial function. Perhaps the elucidation of microglial regulators will offer new therapeutic schemes for treatment of human brain injury.

\section{References}

Beller, D. (1981) Collection of macrophage from the spleen, thymus, and bone marrow. In Manual of Macrophage Methodology, H. B. Horscowitz, H. T. Holden, J. A. Bellanti, and A. Ghaffer, eds., pp. 13-16, Dekker, New York.

Bottenstein, J. E., and G. H. Sato (1979) Growth of rat neuroblastoma cell line in serum-free supplemental medium. Proc. Natl. Acad. Sci. USA $76:$ 514-517.

Boya, J., J. Calvo, and A. Prado (1979) The origin of microglial cells. J. Anat. 129: 177-186.

Brierley, J. B., and A. W. Brown (1982) The origin of lipid phagocytes in the central nervous system: I. The intrinsic microglia. J. Comp. Neurol. 211: 397-406.

Daems, W. T. (1980) Peritoneal macrophages. In The Reticuloendothelial System, Vol. 1, I. Carr and W. T. Daems, eds., pp. 57-127, Plenum, New York.

Davis, P. (1981) Secretory functions of mononuclear phagocytes: Overview and methods for preparing conditioned supernatants. In Methods for Studying Mononuclear Phagocytes, D. O. Adams, P. J. Edelson, and H. Koren, eds., pp. 549-559, Academic, New York.

Dinarello, C. A. (1984) Interleukin-1. Rev. Infect. Dis. 6: 51-56.

Fedoroff, S. (1983) The development of glial cells in primary cultures. In Dynamic Properties of Glial Cells, G. Franck, L. Hertz, E. Schoffeniels, and D. B. Towers, eds., pp. 83-92, Pergamon, Oxford.

Giulian, D. (1984) Peptides from the regenerating central nervous system of goldfish stimulate glia. Proc. Natl. Acad. Sci. USA 81:35673571 .

Giulian, D. (1985) Levels of glia promoting factors change in regen- erating, developing, or traumatized brain. Abstract from the meeting of the American Academy of Neurology, Dallas, TX, April.

Giulian, D., and T. J. Baker (1985) Peptides released by ameboid microglia regulate astroglial proliferation. J. Cell. Biol. 101: 24112415.

Giulian, D., and L. B. Lachman (1985a) Interleukin-1 stimulates astroglial proliferation after brain injury. Science 228: 497-499.

Giulian, D., and L. B. Lachman (1985b) Interleukin-1 as a mediator of the glial response to brain injury. In Cellular and Molecular Biology of Lymphokines, pp. 815-821, Academic, New York.

Giulian, D., T. J. Baker, N. Shih, and L. B. Lachman (in press) Interleukin- 1 of the central nervous system is produced by ameboid microglial. J. Exp. Med.

Giulian, D., Y. Tomozawa, H. Hindman, and R. Allen (1985) Peptides from the regenerating central nervous system promote specific populations of macroglia. Proc. Natl. Acad. Sci. USA 82: 4287-4290.

Innocenti, G. M., S. Clarke, and H. Koppel (1983a) Transitory macrophage in the white matter of the developing visual cortex. I. Light and electron microscopic characteristics and distribution. Dev. Brain Res. 11: 39-54.

Innocenti, G. M., S. Clarke, and H. Koppel (1983b) Transitory macrophage in the white matter of the developing visual cortex. II. Development and relations with axonal pathways. Dev. Brain Res. 11: 55-66.

Johnston, R. B. (1981) Secretion of superoxide anion. In Methods for Studying Mononuclear Phagocytes, D. O. Adams, P. J. Edelson, and H. S. Koren, eds., pp. 489-497, Academic, New York.

Jones-Villeneuve, E. M. V., M. W. McBurney, K. A. Robers, and V. I. Kalnins (1982) Retinoic acid induces embryonal carcinoma cells to differentiate into neurons and glial cells. J. Cell Biol. 94: 253-262.

Kaplow, L. S. (1981) Cytochemical identification of mononuclear macrophages. In Manual of Macrophage Methodology, H. B. Horscowitz, H. T. Holden, J. A. Bellanti, and A. Ghaffer, eds., pp. 199207, Decker, New York.

Kimelberg, H. K. (1983) Primary astrocyte cultures: A key to astrocyte functions. Cell Mol. Neurobiol. 3: 1-16.

Konigsmark, B. W., and R. L. Sidman (1963) Origin of brain macrophages in the mouse. J. Neuropathol. Exp. Neurol. 22: 643-676.

Koski, I. R., D. G. Poplack, and R. M. Blaese (1976) A nonspecific esterase stain for the identification of monocytes and macrophages. In In Vitro Methods in Cell Mediated and Tumor Immunity, B. R. Bloom and I. R. David, eds., pp. 359-362, Academic, New York.

Lee, J. C., II. A. Hupel, and J. N. Ihle (1982) Constitutive production of a unique lymphokine "IL-3" by the WEHI-3 cell line. J. Immunol. 128: 2393-2398.

Leong, S. K., J. Y. Shieh, E. A. Ling, and W. C. Wong (1983) Labeling of ameboid microglial cells in the supraventricular corpus callosum following the application of horseradish peroxidase in the cerebrum and spinal cord in rats. J. Anat. 136: 367-377.

Ling, E. A. (1976) Electron microscopy identification of amoeboid microglia in the spinal cord of newborn rats. Acta Anat. 96: 600609.

Ling, E. A. (1981) The origin and nature of microglia. In Advances in Cellular Neurobiology, Vol. 2, S. Fedoroff and L. Hertz, eds., pp. 3382, Academic, New York.

Ling, E. A., C. Kaur, and W. C. Wang (1982) Light and electron microscopic demonstration of nonspecific esterase in ameboid microglial cells in the corpus callosum in postnatal rates: A cytochemical link to monocytes. J. Anat. 135: 385-394.

Ling, E. A., C. Y. Tseng, F. C. T. Yoon, and W. C. Wong (1983) Isolation and culture of amoeboid microglial cells from the corpus callosum and cavum septum pellucidum in postnatal rats. J. Anat. 137: 223-233.

Matsumoto, Y., and F. Ikuta (1985) Appearance and distribution of fetal brain macrophages in mice. Cell Tissue Res. 239: 271-278.

McCarthy, K., and J. de Vellis (1980) Preparation of separate astroglial and oligodendroglial cell cultures from rat cerebral tissue. J. Cell Biol. 85: 890-902.

Metcalf, D. (1985) The granulocyte-macrophage colony stimulating factors. Science 299: 16-22.

Mosier, D. E. (1981) Separation of murine macrophages by adherence to solid substrates. In Methods for Studying Mononuclear Phagocytes, D. O. Adams, P. J. Edelson, and H. S. Koren, eds., pp. 179-185, Academic, New York.

Murabe, Y., and Y. Sano (1982) Morphological studies on neuroglia 
VI. Postnatal development of microglial cells. Cell Tissue Res. 225: 464-485.

Ochmichen, M. (1983) Inflammatory cells in the central nervous system. Prog. Neuropathol. 5: 277-325.

Ogawa, I., H. K. Koerten, and W. T. Daems (1978) Peroxidase activity in monocytes and tissue macrophages. Cell Tissue Res. 188: 361373.

Pitas, R. E., T. L. Innerarity, J. N. Weinstein, and R. W. Mahley (1981) Acetoacetylated lipoproteins used to distinguish fibroblasts from macrophages in vitro by fluorescence microscopy. Arteriosclerosis $1: 177-$ 185.

Privat, A., and J. Fulcrand (1977) In Cell, Tissue, and Organ Culture in Neurobiology, S. Fedoroff and L. Hertz, eds., pp. 11-37, Academic, New York.

Raff, M. C., K. L. Fields, S. Hakomori, R. Mirsky, R. M. Pruss, and J. Winter (1979) Cell type specific markers for distinguishing and studying neurons and the major classes of glial cells in culture. Brain Res. 174: 283-308.

Rio-Hortega, P. del (1932) Microglia. In Cytology and Cellular Pathology of the Nervous System, Vol. 2, W. Penfield, ed., pp. 481-584, Paul P. Hocker, New York.

Sone, S., C. Bucana, L. C. Hoyer, and I. J. Fidler (1981) Kinetics and ultrastructure studies of the induction of rat alveolar macrophage fusion by mediators released from mitogen-stimulated lymphocytes. Am. J. Pathol. 103: 234-246.

Springer, T. A., and M. K. Ho (1982) Macrophage differentiation antigens: Markers of macrophage subpopulations and tissue localization. In Hybridomas in Cancer Diagnosis and Treatment, M. S. Mitchell and H. F. Oettgen, eds., pp. 35-46, Raven, New York.
Stensaas, L. J., and W. H. Reichart (1971) Round and ameboid microglial cells in the neonatal rabbit brain. Z. Zellforsch. 119: 147163.

Thiele, D. L., M. Kurosaka, and P. E. Lipsky (1983) Phenotype of the accessory cell necessary for mitogen-stimulated $T$ and $B$ cell responses in human peripheral blood: Delineation by its sensitivity to the lysosomotrophic agent, L-leucine methyl ester. J. Immunol. 131:22822290.

Torvik, A. (1975) The relationship between microglia and brain macrophages. Experimental investigations. Acta Neuropathol. (Suppl. VI): 297-300.

Tseng, C. Y., E. A. Ling, and W. C. Wong (1983) Scanning electron microscopy of ameboid microglial cells in the transient cavum septum pellucidum in pre- and postnatal rats. J. Anat. 136: 251-263.

Valentino, K. L., and E. G. Jones (1981) Morphological and immunocytochemical identification of macrophages in the developing corpus callosum. Anat. Embryol. 163: 157-172.

Wang, S. Y., G. J. LaRosa, and L. J. Gudas (1985) Molecular cloning of gene sequences transcriptionally regulated by retinoic acid and dibutyryl cyclic AMP in cultured mouse teratocarcinoma cells. Dev. Biol. 107: 75-86.

Widmann, J., and D. D. Fahimi (1976) Proliferation of endothelial cells in estrogen-stimulated rat liver. Lab. Invest. 34: 141-149.

Wisse, E. (1977) Ultrastructure and function of Kupffer cells and other sinusoidal cells in the liver. In The Kupffer Cells, D. L. Knook and E. Wisse, eds., pp. 30-60, Elsevier, Amsterdam. 